\title{
Xenology: The enigma of xenon in carbonaceous chondrites
}

\author{
P. K. KURODA \\ Department of Chemistry, University of Arkansas, Fayetteville, \\ Arkansas 72701 U.S.A.
}

(Received July 4, 1976)

\begin{abstract}
The isotopic composition of the enigmatic xenon component (the so-called Renazzo-type fission xenon, $C C F$ or $X$ ), which is said to be released from carbonaceous chondrites at temperatures 600 to $1,000^{\circ} \mathrm{C}$, is explained in terms of the variation of the isotopic ratios due to a combined effect of massfractionation, neutron capture and cosmic-ray irradiation processes, which took place during the early history of the solar system.
\end{abstract}

\section{INTRODUCTION}

Thirteen years ago, REYNOLDs (1963) published a paper entitled Xenology, in which he stated that "xenology means to us the detailed study of the abundance of Xe isotopes evolved from meteorites by heating or other means and the inferences that can be drawn from these studies about the early history of the meteorites and the solar system. To the classicist xenology means study of a strange substance, which is also appropriate". The history of xenology dates back to three years earlier, when REYNOLDS $(1960 \mathrm{a}, \mathrm{b})$ made the suggestion that the carbonaceous chondrite Murray contains a fission xenon component. This idea eventually evolved into the theory that a strange xenon component called Renazzo-type fission xenon (REynolds and TuRner, 1964; Funk et al., 1967), CCF (Podosek et al., 1971) or $X$ (MANuEL et al., 1972b) exists in carbonaceous chondrites and it is released at temperatures 600 to $1,000^{\circ} \mathrm{C}$ (for a complete list of references on this subject, see KURODA et al., 1974, 1975).

The idea of the existence of a strange xenon component in meteorites is reminiscent of the 18 th century theory of phlogiston, according to which all combustible bodies were to be regarded as compounds, one of their constituents being phlogiston. According to Manuel et al. (1972b), carbonaceous chondrites contain two isotopically distinct components of xenon, one of them being xenon $X$. Xenon $X$ escapes from the meteorites at temperatures 600 to $1,000^{\circ} \mathrm{C}$, but its isotopic composition can not be clearly defined. LEWIS et al. (1975) have recently re- ported that they succeeded in isolating the host phase of a xenon $X$-like substance by etching the carbonaceous chondrite Allende with various acids. This was followed by the claim by ANDERs et al. (1975) that the progenitor of this strange xenon component may be one of the volatile heavy elements 113 to 115 . The theory of ANDERS et al. (1975), however, does not explain the origins of the light xenon isotopes, which accompany $X$ (BLACK, 1975; Clayton, 1975, 1976).

It is more likely that xenon $X$ or the Renazzo-type fission xenon, like phlogiston, does not really exist in nature. It is possible to demonstrate this by paying attention to the amounts and the isotopic compositions of not only the xenon fractions released from the meteorites at various temperatures, but also to those of the xenon fractions remaining in the meteorites during stepwise-heating experiments (KURODA, $1976 a, b, c)$. In the present work, this new approach was incorporated into the earlier method of interpretation for the xenon isotope anomalies (KURODA, 1971; Kuroda et al., 1974, 1975).

\section{EXPERIMENTAL DATA}

The following xenon isotope data were reexamined in the present study: Renazzo data by REYNOLDS and TURNER (1964); Mokoia data by Rowe (1968); Allende data by PHINNEY (1971); Allende and Mokoia data by MANUEL et al. (1972a); Murray data by KuRODA et al. (1974); Murchison data by KURODA et al. 


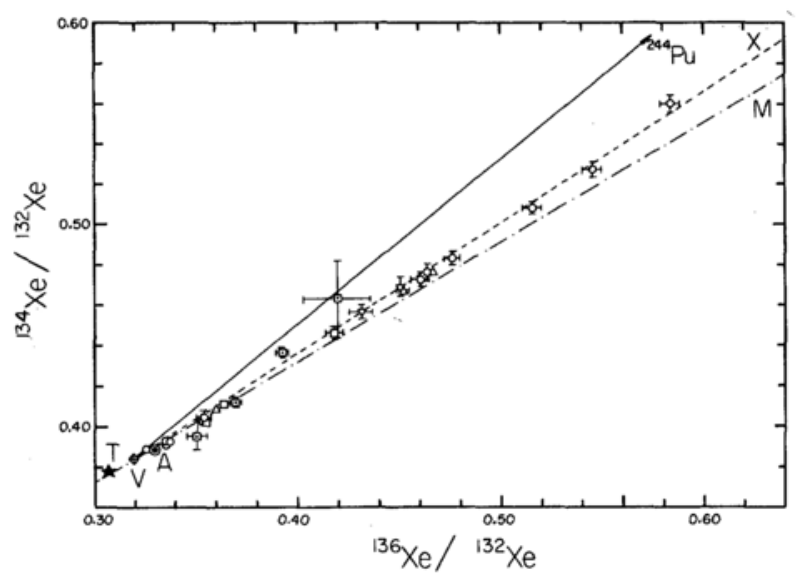

Fig. 1. Correlation plot for ${ }^{134} \mathrm{Xe} /{ }^{132} \mathrm{Xe}$ versus ${ }^{136} \mathrm{Xe} /$ ${ }^{132} \mathrm{Xe}$ for the xenon fractions obtained from the carbonaceous chondrites Allende and Mokoia.

○ : Allende (LEWIS et al., 1975)

$\triangle:$ Allende (MANUEL et al., 1972a)

$\nabla:$ Allende (PHINNEY, 1971)

口 : Mokoia (MANUEL et al., 1972a)

๑ : Mokoia matrix (RowE, 1968)

- : Atmospheric xenon $(A)$

$\diamond:$ AVCC xenon (V)

$\star$ : SABU et al.'s trapped xenon (T)

(1975); and Allende data by Lewis et al. (1975).

\section{RESUlts AND Discussion}

Figure 1 shows a plot of ${ }^{134} \mathrm{Xe} /{ }^{132} \mathrm{Xe}$ versus ${ }^{136} \mathrm{Xe} /{ }^{132} \mathrm{Xe}$ for Allende and Mokoia. The data points fall on the straightline $T X$, where $T$ is $\mathrm{S} \mathrm{ABU}$ et al.'s trapped xenon (SABU et al., 1974). The slope of the line $T X$ is slightly different from that of the line $T M$ representing the variation of the isotopic ratios by mass-fractionation. The results shown in Fig. 1 are commonly explained by assuming that the xenon fractions released from the meteorites are mixtures of $X$ and a trapped component $T$ (MANUEL et al., 1972b; SABU et al., 1974).

Figure 2 shows a plot of ${ }^{130} \mathrm{Xe} /{ }^{132} \mathrm{Xe}$ versus ${ }^{136} \mathrm{Xe} /{ }^{132} \mathrm{Xe}$ for Allende and Mokoia. The data points are scattered and a number of correlation lines such as $T X, T L, T X^{\prime}, T X^{\prime \prime}$, etc. can be drawn each through a few data points.

An extension of the line $V A$ connecting the isotopic compositions of AVCC xenon $(V)$ and of the atmospheric xenon $(A)$ to ${ }^{130} \mathrm{Xe}=0$ leads to the fission mass-yield spectrum for the so-called KURODA-type fission xenon, in which the abundance at mass number 132 is abnor-

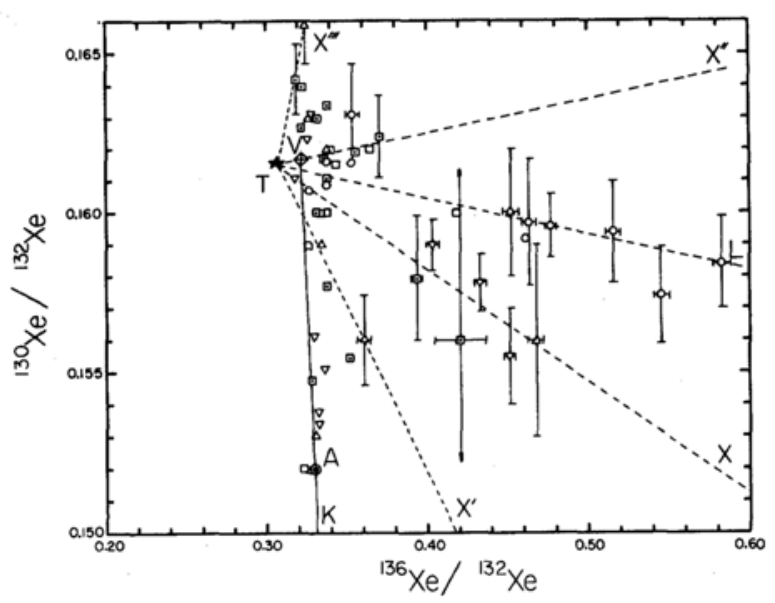

Fig. 2. Correlation plot for ${ }^{130} \mathrm{Xe} /{ }^{132} \mathrm{Xe}$ versus ${ }^{136} \mathrm{Xe} /$ ${ }^{132} \mathrm{Xe}$ for the xenon fractions obtained from the carbonaceous chondrites Allende and Mokoia. Notation is that used in Fig. 1.

mally high (KuRodA, 1960). Similarly, an extension of the line $T L$ to ${ }^{130} \mathrm{Xe}=0$ leads to the fission mass-yield spectrum obtained by LEwIS et al. (1975), in which the abundance at mass number 132 is abnormally low. An extension of the line $T X$ to ${ }^{130} \mathrm{Xe}=0$, on the other hand, leads to the fission mass-yield spectrum for the Renazzo-type fission xenon (REYNOLDS and TURNER, 1964). An extension of the line TX", which has a positive slope, on the other hand, leads to a fission mass-yield spectrum, in which the abundance at mass number 132 is negative.

Figure 3 shows a plot of ${ }^{131} \mathrm{Xe} /{ }^{132} \mathrm{Xe}$ versus

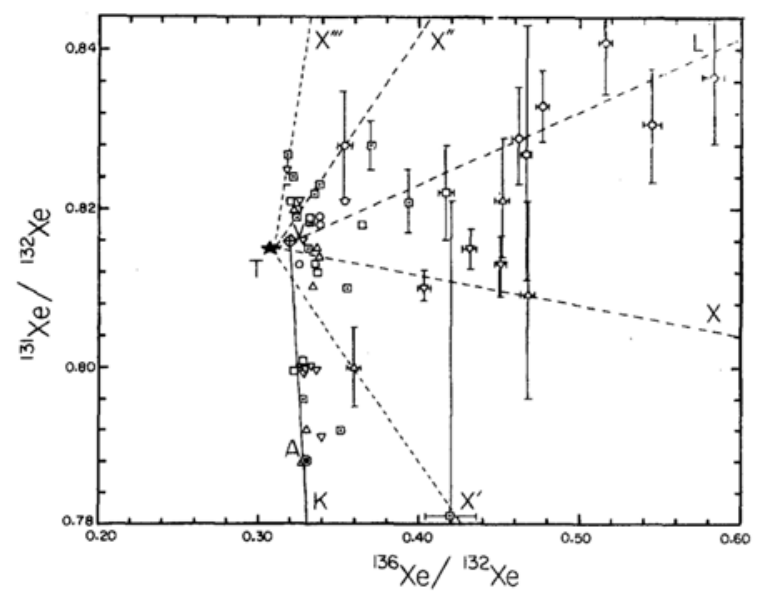

Fig. 3. Correlation plot for ${ }^{131} \mathrm{Xe} /{ }^{132} \mathrm{Xe}$ versus ${ }^{136} \mathrm{Xe} /$ ${ }^{132} \mathrm{Xe}$ for the xenon fractions obtained from the carbonaceous chondrites Allende and Mokoia. Notation is that used in Fig. 1. 


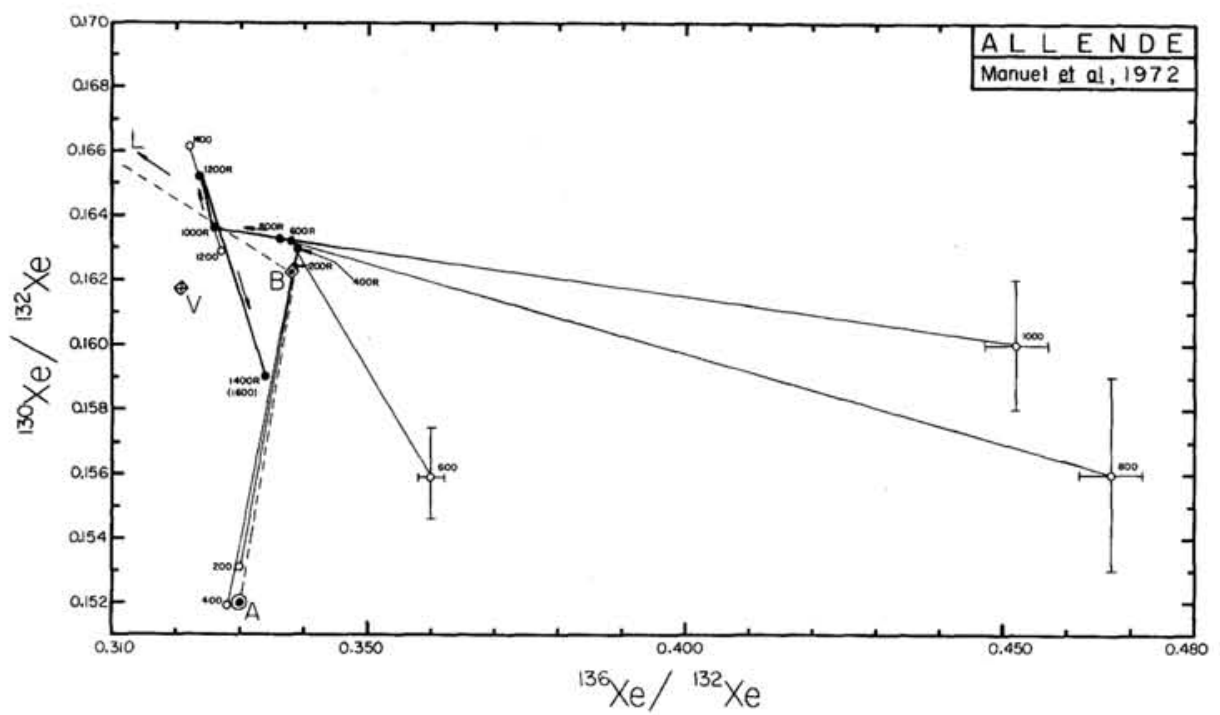

Fig. 4. ${ }^{130} \mathrm{Xe} /{ }^{132} \mathrm{Xe}$ versus ${ }^{136} \mathrm{Xe} /{ }^{132} \mathrm{Xe}$ for the xenon in Allende (MANUEL et al., 1972a). The letter $R$ refers to the xenon, which is retained by the meteorite at the release temperature.
$\diamond:$ Bulk meteorite $(B)$.
$L:$ Xenon in luna fines.

${ }^{136} \mathrm{Xe} /{ }^{132} \mathrm{Xe}$ for Allende and Mokoia. The data points are again scattered and correlation lines such as $T X, T L, T X^{\prime}, T X^{\prime \prime}$, etc., can be drawn each through a number of data points. These results clearly indicate that the experimental data can not be explained in terms of a simple model, such as employed by REYNOLDS and TuRNER (1964), RowE (1968), MANUEL et al. (1972b), $\mathrm{S} \mathrm{ABU}$ et al. (1974), LEWIS et al. (1975) and others.

Figure 4 shows a plot of ${ }^{130} \mathrm{Xe} /{ }^{132} \mathrm{Xe}$ versus ${ }^{136} \mathrm{Xe} /{ }^{132} \mathrm{Xe}$ for the Allende data obtained by
MANUEL et al. (1972a) in stepwise-heating experiments. Note that the isotopic compositions of not only the xenon fractions released at each temperature but also those of the xenon being retained by the meteorite, are plotted here. The isotopic compositions of the xenon fractions released at 200 and $400^{\circ} \mathrm{C}$ are similar to the atmospheric xenon $(A)$ and hence the isotopic composition $(B)$ of the xenon, which is retained by the meteorite, moves away from the point $A$. As the temperature is raised above $600^{\circ} \mathrm{C}$, the isotopic composition of the xenon,

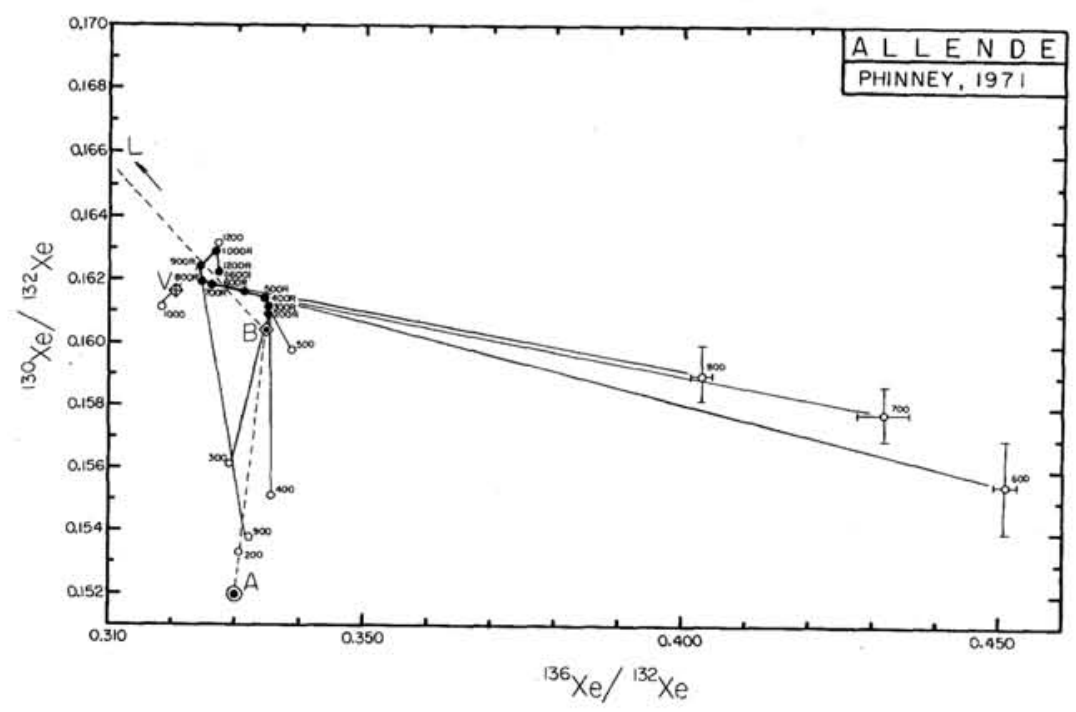

Fig. 5. ${ }^{130} \mathrm{Xe} /{ }^{132} \mathrm{Xe}$ versus ${ }^{136} \mathrm{Xe} /{ }^{132} \mathrm{Xe}$ for the xenon in Allende (PHINNEY, 1971). 


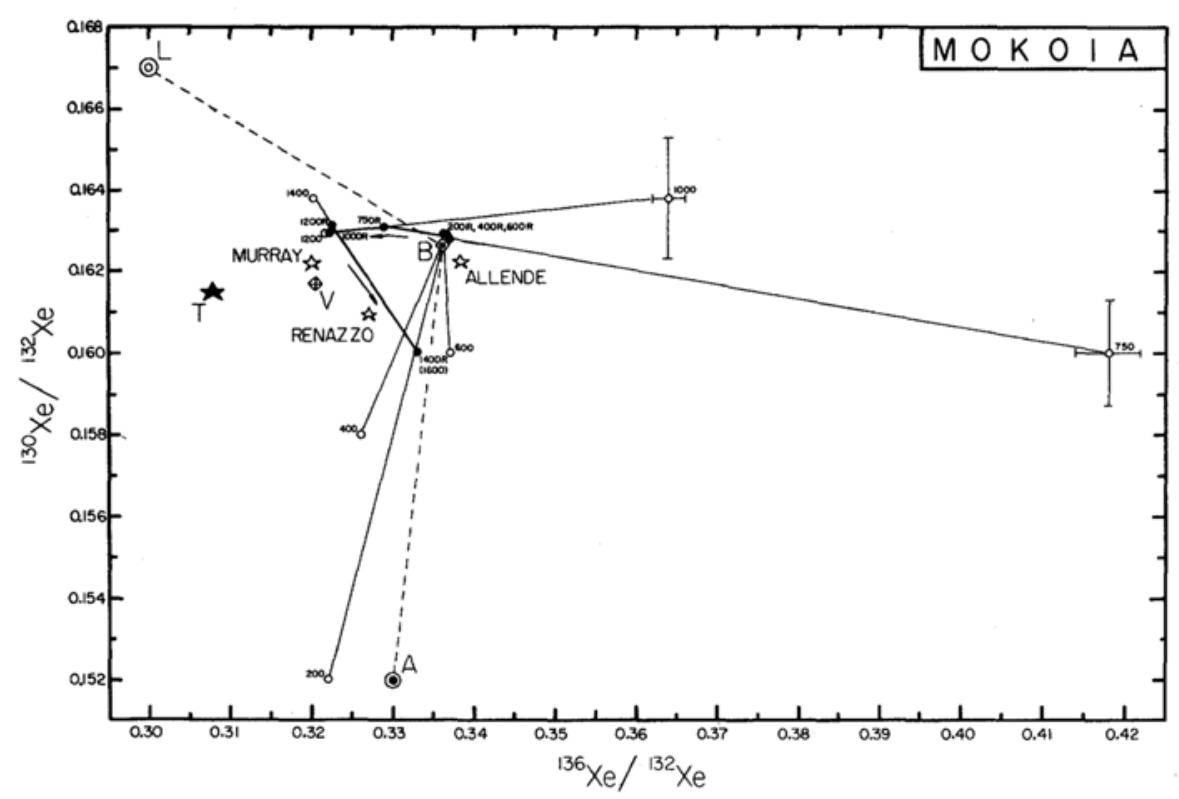

Fig. 6. ${ }^{130} \mathrm{Xe} /{ }^{132} \mathrm{Xe}$ versus ${ }^{136} \mathrm{Xe} /{ }^{132} \mathrm{Xe}$ for the xenon in Mokoia. (MANUEL et al. 1972a). 0 : Lunar fines (PEPIN et al., 1970).

which is remaining in the meteorite, shifts almost horizontally to the left toward the $1,000^{\circ} \mathrm{C}$ point. The xenon fractions being retained by the meteorite at temperatures above $1,000^{\circ} \mathrm{C}$, appear to be two-component mixtures of the xenon fractions, which are released at $1,400^{\circ} \mathrm{C}$ and $1,600^{\circ} \mathrm{C}$. Figure 5 shows a similar plot of ${ }^{130} \mathrm{Xe} /{ }^{132} \mathrm{Xe}$ versus ${ }^{136} \mathrm{Xe} /{ }^{132} \mathrm{Xe}$ for the Allende data obtained by PhinNey (1971) in stepwiseheating experiments.

Figure 6 shows a plot of ${ }^{130} \mathrm{Xe} /{ }^{132} \mathrm{Xe}$ versus ${ }^{136} \mathrm{Xe} /{ }^{132} \mathrm{Xe}$ for the Mokoia data obtained by
Manuel et al. (1972a) in stepwise-heating experiments. The pattern of variation of the isotopic composition is again similar to that seen for Allende, but the data point for the xenon fraction released at $1,000^{\circ} \mathrm{C}$ deviates upward away from the direction pointing toward $X$. The Mokoia $1,000^{\circ} \mathrm{C}$ data point was ignored by MANUEL et al. (1972b), but it appears that the fact that this data point shows such a deviation should not be explained away simply as being due to an experimental error. Figure 7 shows a similar plot of ${ }^{130} \mathrm{Xe} /{ }^{132} \mathrm{Xe}$ versus ${ }^{136} \mathrm{Xe} /$

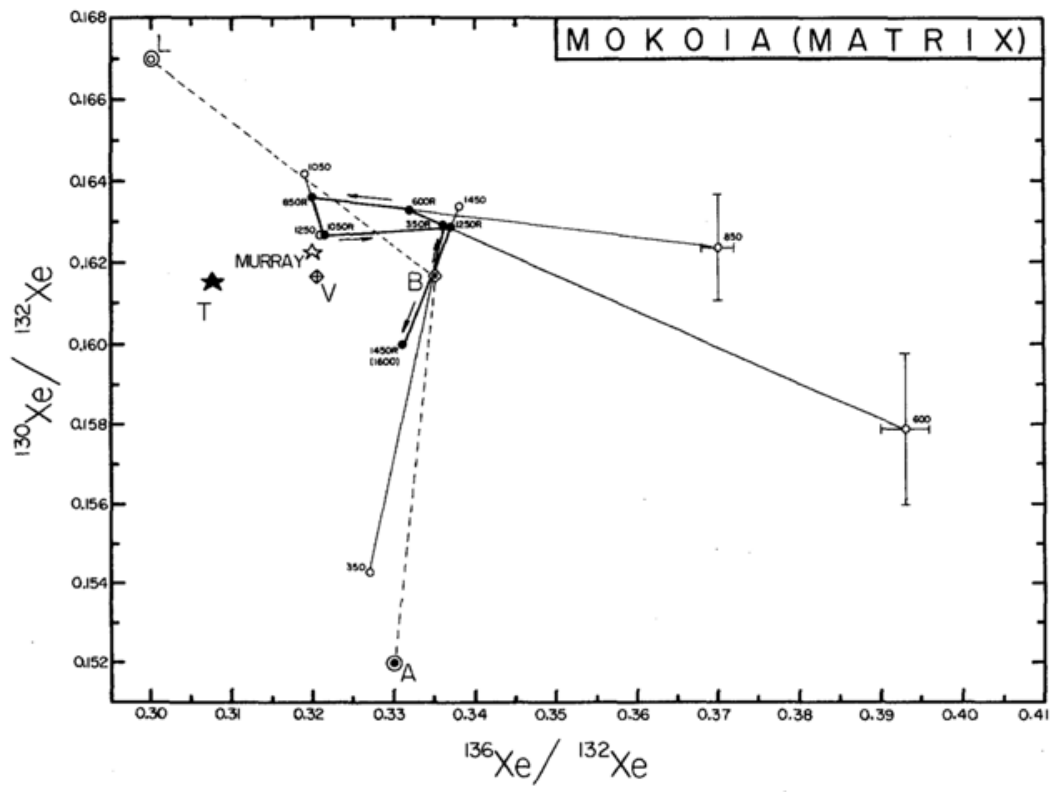

Fig. 7. ${ }^{130} \mathrm{Xe} /{ }^{132} \mathrm{Xe}$ versus ${ }^{136} \mathrm{Xe} /{ }^{132} \mathrm{Xe}$ for the xenon in Mokoia matrix (RowE, 1968) O: Lunar fines (PEPIN et al., 1970). 


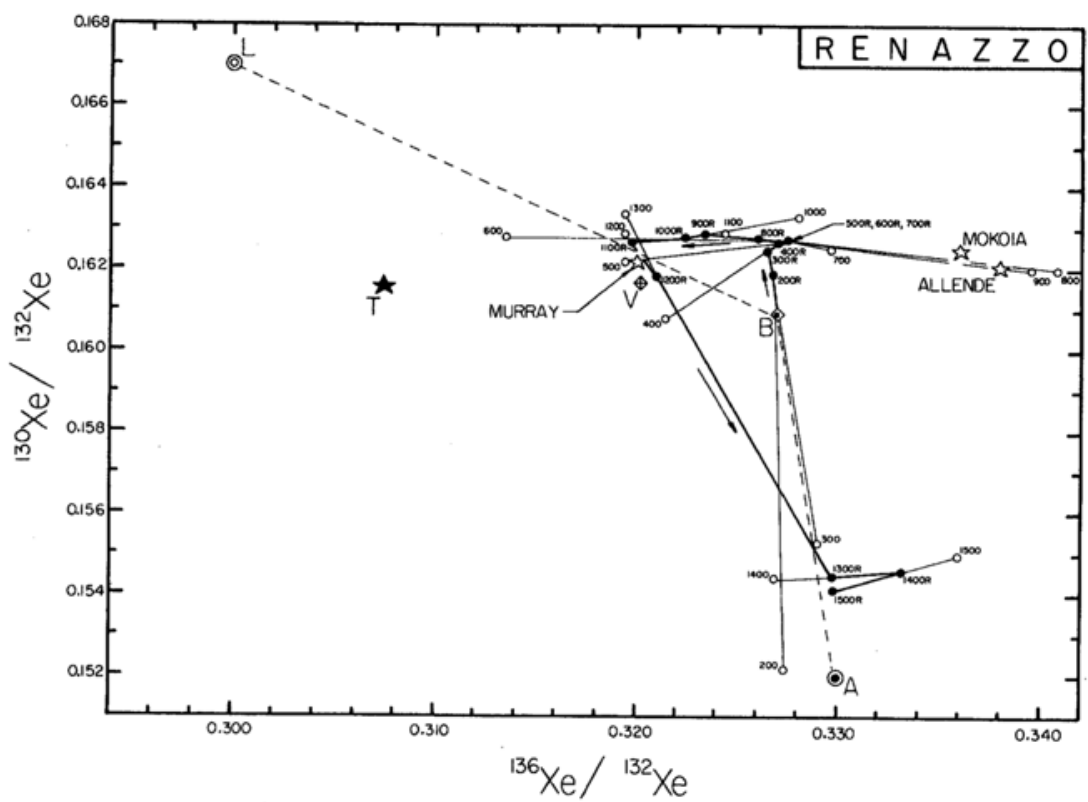

Fig. 8. ${ }^{130} \mathrm{Xe} /{ }^{132} \mathrm{Xe}$ versus ${ }^{136} \mathrm{Xe} /{ }^{132} \mathrm{Xe}$ for the xenon in Renazzo (REYNOLDS and TURNER, 1964).

${ }^{132} \mathrm{Xe}$ for the Mokoia matrix data obtained by Rowe (1968) in stepwise-heating experiments. It is interesting to note that the data point for the xenon fraction released at $850^{\circ} \mathrm{C}$ displays a similar trend which we have noted earlier for the $1,000^{\circ} \mathrm{C}$ fraction of Mokoia.

Figure 8 shows a plot of ${ }^{130} \mathrm{Xe} /{ }^{132} \mathrm{Xe}$ versus ${ }^{136} \mathrm{Xe} /{ }^{132} \mathrm{Xe}$ for the Renazzo data obtained by REYNOLDS and TURNER (1964) in stepwise-heating experiments. The data points for the xenon fractions released from Renazzo in the temperature range between $600^{\circ} \mathrm{C}$ to $1,200^{\circ} \mathrm{C}$ appear to fall on a line connecting the $600^{\circ} \mathrm{C}$ and $800^{\circ} \mathrm{C}$ data points, which has a very slight negative slope. REYNOLDS and TURNER (1964) have interpreted this trend as being due to the fact that the xenon fractions released from Renazzo contain mixtures of two components of xenon: (a) a trapped component, whose isotopic composition is represented by that of the xenon released at $600^{\circ} \mathrm{C}$ and (b) a fission component or the so-called Renazzo-type fission xenon, whose isotopic composition lies off-scale far to the lower-right of Fig. 8. The data points for the

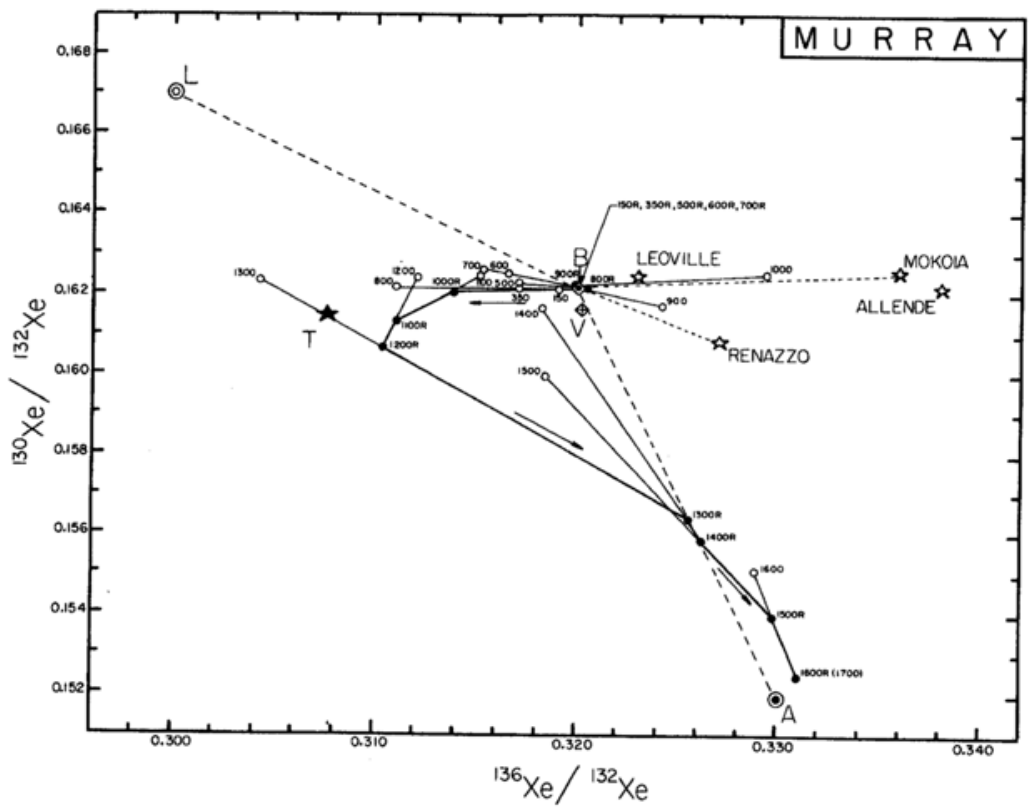

Fig. 9. ${ }^{130} \mathrm{Xe} /{ }^{132} \mathrm{Xe}$ versus ${ }^{136} \mathrm{Xe} /{ }^{132} \mathrm{Xe}$ for the xenon in Murray (KURODA et al., 1974). 


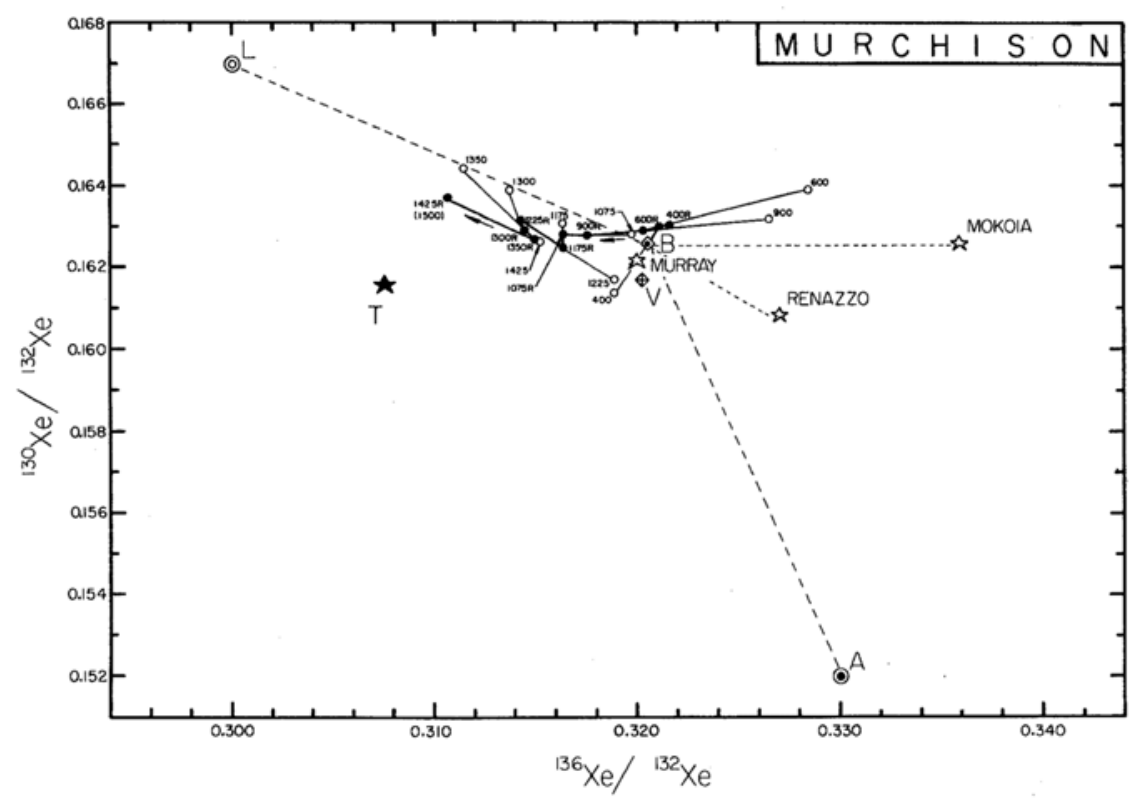

Fig. 10. ${ }^{130} \mathrm{Xe} /{ }^{132} \mathrm{Xe}$ versus ${ }^{136} \mathrm{Xe} /{ }^{132} \mathrm{Xe}$ for the xenon in Murray (KURODA et al., 1975).

xenon fractions retained by the meteorite in the temperature range 400 to $1,100^{\circ} \mathrm{C}$ appear to fall on this line, but the slope of this correlation line does not point toward the isotopic composition $(T)$ of SABU et al.'s trapped xenon (SABU et al., 1974). Moreover, it seems that a correlation line with a slope of almost zero can be drawn, if the data point for the xenon released at $500^{\circ} \mathrm{C}$ is not ignored.

Figure 9 shows a plot of ${ }^{130} \mathrm{Xe} /{ }^{132} \mathrm{Xe}$ versus ${ }^{136} \mathrm{Xe} /{ }^{132} \mathrm{Xe}$ for the Murray data obtained by KURODA et al. (1974). The pattern of variation of the isotopic compositions of the xenon in the bulk sample of Murray during stepwise heating experiments is analogous to that we have seen for Renazzo, except for the fact that the $1,200^{\circ} \mathrm{C}$ data point lies near the trapped xenon (T) of S $\mathrm{ABU}$ et al. (1974).

Figure 10 shows a plot of ${ }^{130} \mathrm{Xe} /{ }^{132} \mathrm{Xe}$ versus ${ }^{136} \mathrm{Xe} /{ }^{132} \mathrm{Xe}$ for the Murchison data obtained by KURODA et al. (1975). The isotopic composition $(B)$ of the xenon being retained by the meteorite changes toward the general direction of the data point $(L)$ for the bulk lunar fines 10084 (PEPIN et al., 1970).

While it is difficult to explain these variations of the isotopic ratios by introducing the concept of a hypothetical xenon component such as $X$ or the Renazzo-type fission xenon, it seems that the experimental data can be interpreted in a more reasonable manner by considering the fact that the isotopic compositions of the xenon in meteorites can be altered by a combined effect of a) mass-fractionation, b) neutron-capture and c) cosmic-ray irradiation processes which took place in the early history of the solar system (Kuroda, 1971). The new interpretation for the general isotope anomalies observed in xenon can be expressed in a mathematical from as

$$
\begin{gathered}
\left(1+b_{136}\right)\left({ }^{i} \mathrm{Xe} /{ }^{136} \mathrm{Xe}\right)_{M}=\left({ }^{i} \mathrm{Xe} /{ }^{136} \mathrm{Xe}\right)_{A} \\
\left(1+f_{\mathrm{i}}\right)+a_{\mathrm{i}}+b_{\mathrm{i}}+c_{\mathrm{i}}
\end{gathered}
$$

where the subscripts $M$ and $A$ refer to the meteorites and the atmosphere, respectively; $i$ is the mass number; $f_{\mathrm{i}}$ is a mass-fractionation factor; $a_{\mathrm{i}}, b_{\mathrm{i}}$ and $c_{\mathrm{i}}$ are the contributions from the processes of neutron capture, fission and spallation, respectively, at mass number $i$; and $b_{136}$ is the value of $b_{\mathrm{i}}$ at mass number 136 (KURODA et al., 1974).

Table 1 shows the isotopic compositions of xenon in a number of carbonaceous chondrites. Since the carbonaceous chondrites contain generally much greater amounts of xenon than ordinary meteorites, the contribution $\left(b_{\mathrm{i}}\right)$ from the spontaneous fission of ${ }^{244} \mathrm{Pu}$ is expected to be negligibly small and hence in comparing the isotopic compositions of xenon in various carbonaceous chondrites equation (1) may be written in a simplified form as 
The enigma of xenon

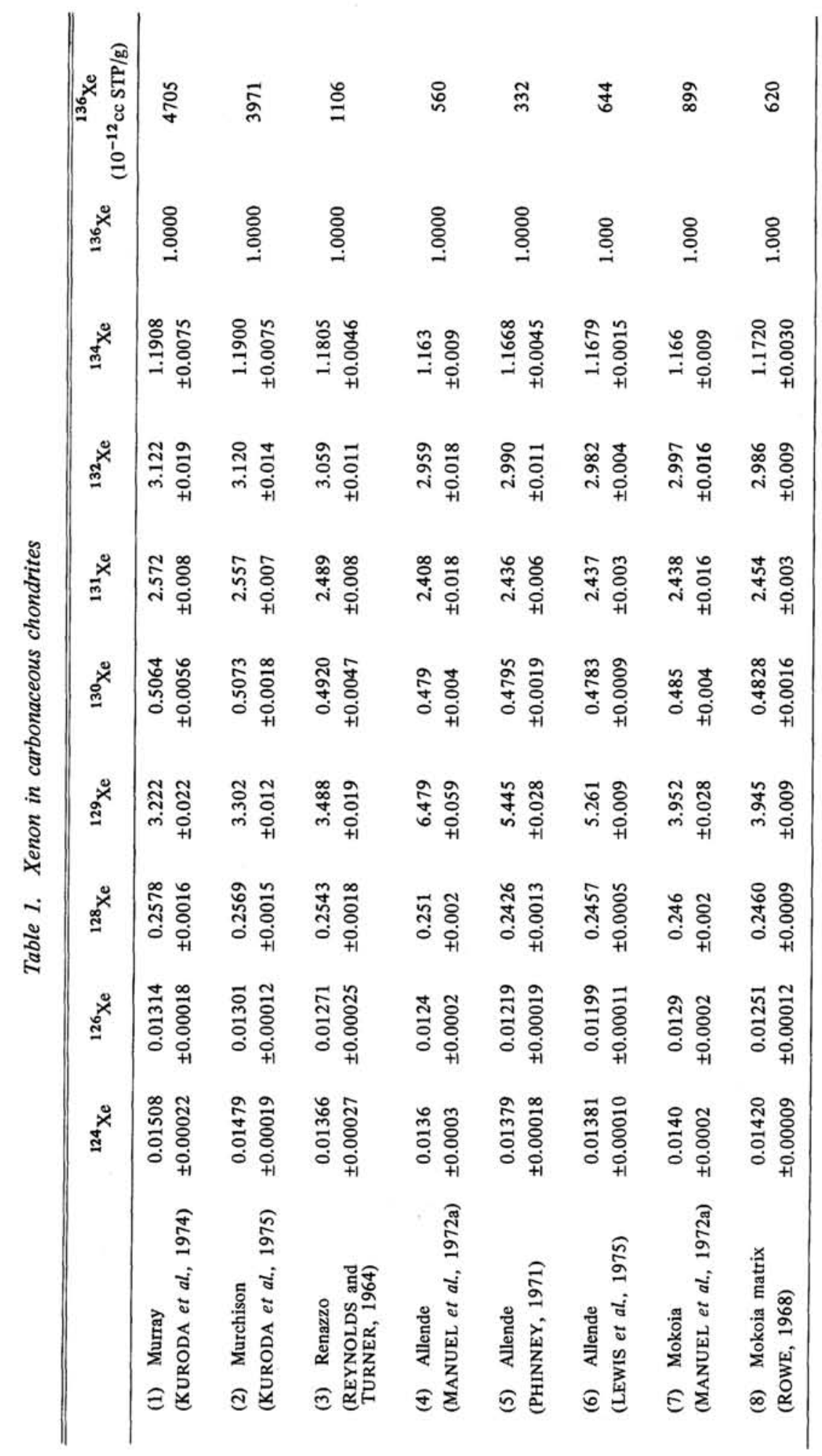




$$
Q^{\mathrm{i}}=\left(V^{\mathrm{i}}+\Delta_{\mathrm{i}}\right)\{1+(136-i) \cdot \mu\}
$$

where $V^{i}$ and $Q^{i}$ are the ${ }^{i} \mathrm{Xe} /{ }^{136} \mathrm{Xe}$ ratios for the AVCC xenon and the xenon found in a sample of meteorite, respectively, and $\mu$ is a massfractionation factor expressed in terms of unit mass difference.

One may be able to make a further assumption that $\Delta_{134} \ll V^{134}$ since the abundance of ${ }^{134} \mathrm{Xe}$ is not likely to be altered significantly by the processes of cosmic-ray irradiation and neutron-capture. Hence we have

$$
Q^{134}=V^{134}(1+2 \mu),
$$

and

$$
\mu=\frac{Q^{134}-V^{134}}{2 V^{134}}
$$

Table 2 shows the values of $\mu$ and $\Delta_{i}$ calculated from equations (2) and (3) for a number of carbonaceous chondrites. In these calculations, the isotopic composition of the xenon in Murray (Kuroda et al., 1974) was used for $V^{i}$ in equations (2) and (3). It is noteworthy that the values of $\Delta_{131}$ and $\Delta_{132}$ thus calculated are small compared with the values of $Q^{131}$ and $Q^{132}$, respectively, and these results seem to indicate that the relative abundances of the heavy xenon isotopes ${ }^{131} \mathrm{Xe},{ }^{132} \mathrm{Xe},{ }^{134} \mathrm{Xe}$ and ${ }^{136} \mathrm{Xe}$ are altered primarily by the process of mass fractionation, as it was first pointed out by Kuroda and MANUEL (1970). Since the abundances of the light isotopes ${ }^{124} \mathrm{Xe},{ }^{126} \mathrm{Xe}$ and ${ }^{128} \mathrm{Xe}$ are much lower than those of the heavier isotopes, the effect of the cosmic-ray irradia- tion and neutron capture processes are expected to be clearly noticeable (KURODA, 1971). The values of $\Delta_{124}, \Delta_{126}$, and $\Delta_{128}$ are all positive and are not negligibly small compared with the values of $Q^{124}, Q^{126}$ and $Q^{128}$. The values of $\Delta_{130}$ for Allende and Mokoia are also positive and suggest that there is an excess of ${ }^{130} \mathrm{Xe}$ in these meteorites.

According to KURODA (1971), the abundances of ${ }^{124} \mathrm{Xe}$ and ${ }^{126} \mathrm{Xe}$ in carbonaceous chondrites can be altered significantly by the cosmic-ray irradiation (see also KURODA et al., 1974), while both the cosmic-ray irradiation and neutron capture processes may contribute to the alterations of the abundances of ${ }^{128} \mathrm{Xe}$, ${ }^{130} \mathrm{Xe},{ }^{131} \mathrm{Xe}$ and ${ }^{132} \mathrm{Xe}$ and hence we have

$$
\begin{aligned}
& \Delta_{124}=c_{124} \\
& \Delta_{126}=c_{126} \\
& \Delta_{128}=c_{128}+a_{128} \\
& \Delta_{130}=c_{130}+a_{130} \\
& \Delta_{131}=c_{131}+a_{131}
\end{aligned}
$$

and

$$
\Delta_{132}=c_{132}+a_{132}
$$

\begin{tabular}{|c|c|c|c|c|c|c|c|c|}
\hline & & $\mu$ & $\Delta_{124}$ & $\Delta_{126}$ & $\Delta_{128}$ & $\Delta_{130}$ & $\Delta_{131}$ & $\Delta_{132}$ \\
\hline (1) & $\begin{array}{l}\text { Renazzo } \\
\text { (REYNOLDS and TURNER, 1964) }\end{array}$ & -0.004325 & $\begin{array}{l}-0.00064 \\
\pm 0.00025\end{array}$ & $\begin{array}{l}+0.00046 \\
\pm 0.00014\end{array}$ & $\begin{array}{l}+0.0056 \\
\pm 0.0021\end{array}$ & $\begin{array}{l}-0.0013 \\
\pm 0.0030\end{array}$ & $\begin{array}{l}-0.028 \\
\pm 0.015\end{array}$ & $\begin{array}{l}-0.009 \\
\pm 0.015\end{array}$ \\
\hline (2) & $\begin{array}{l}\text { Allende } \\
\text { (MANUEL } \text { et al., 1972a) }\end{array}$ & -0.01167 & $\begin{array}{l}+0.00070 \\
\pm 0.00030\end{array}$ & $\begin{array}{l}+0.00091 \\
\pm 0.00021\end{array}$ & $\begin{array}{l}+0.0191 \\
\pm 0.0021\end{array}$ & $\begin{array}{l}+0.0087 \\
\pm 0.0043\end{array}$ & $\begin{array}{l}-0.015 \\
\pm 0.009\end{array}$ & $\begin{array}{l}-0.018 \\
\pm 0.019\end{array}$ \\
\hline (3) & $\begin{array}{l}\text { Allende } \\
\text { (PHINNEY, 1971) }\end{array}$ & -0.01008 & $\begin{array}{l}+0.00060 \\
\pm 0.00017\end{array}$ & $\begin{array}{l}+0.00041 \\
\pm 0.00022\end{array}$ & $\begin{array}{l}+0.0061 \\
\pm 0.0014\end{array}$ & $\begin{array}{l}+0.0039 \\
\pm 0.0021\end{array}$ & $\begin{array}{l}-0.006 \\
\pm 0.009\end{array}$ & $\begin{array}{l}-0.006 \\
\pm 0.009\end{array}$ \\
\hline (4) & $\begin{array}{l}\text { Allende } \\
\text { (LEWIS } \text { et al., 1975) }\end{array}$ & -0.009615 & $\begin{array}{l} \pm 0.00054 \\
\pm 0.00012\end{array}$ & $\begin{array}{l}+0.00012 \\
\pm 0.00001\end{array}$ & $\begin{array}{l}+0.0083 \\
\pm 0.0006\end{array}$ & $\begin{array}{l}+0.0013 \\
\pm 0.0009\end{array}$ & $\begin{array}{l}-0.012 \\
\pm 0.004\end{array}$ & $\begin{array}{l}-0.021 \\
\pm 0.004\end{array}$ \\
\hline (5) & $\begin{array}{l}\text { Mokoia } \\
\text { (MANUEL et al., 1972a) }\end{array}$ & 1046 & $\begin{array}{l}+0.00092 \\
\pm 0.00024\end{array}$ & $\begin{array}{l}+0.00118 \\
\pm 0.0002\end{array}$ & $\begin{array}{l}+0.0110 \\
\pm 0.002\end{array}$ & $\begin{array}{l}+0.010 \\
\pm 0.004\end{array}$ & $\begin{array}{l}+0.001 \\
\pm 0.018\end{array}$ & $\begin{array}{l}+0.007 \\
\pm 0.019\end{array}$ \\
\hline (6) & $\begin{array}{l}\text { Mokoia matrix } \\
\text { (ROWE, 1968) }\end{array}$ & -0.007810 & $\begin{array}{l}+0.00057 \\
\pm 0.00010\end{array}$ & $\begin{array}{l}+0.00046 \\
\pm 0.00013\end{array}$ & $\begin{array}{l}+0.0049 \\
\pm 0.0010\end{array}$ & $\begin{array}{l}+0.000 \\
\pm 0.002\end{array}$ & $\begin{array}{l}-0.016 \\
\pm 0.006\end{array}$ & $\begin{array}{l}-0.039 \\
\pm 0.010\end{array}$ \\
\hline
\end{tabular}

where the values of $a_{\mathrm{i}}$ for $i=128-132$ are usually about one order of magnitude greater than the values of $c_{\mathrm{i}}$.

Figure 11 shows the variations of $\mu$ and $\Delta_{\mathrm{i}}$ for the xenon fractions remaining in Renazzo

Table 2. Values of $\mu$ and $\Delta_{i}$ for carbonaceous chondrites. In calculating these values, the isotopic composition of xenon in Murray was used for $V^{i}$ in equations (2) and (3). 

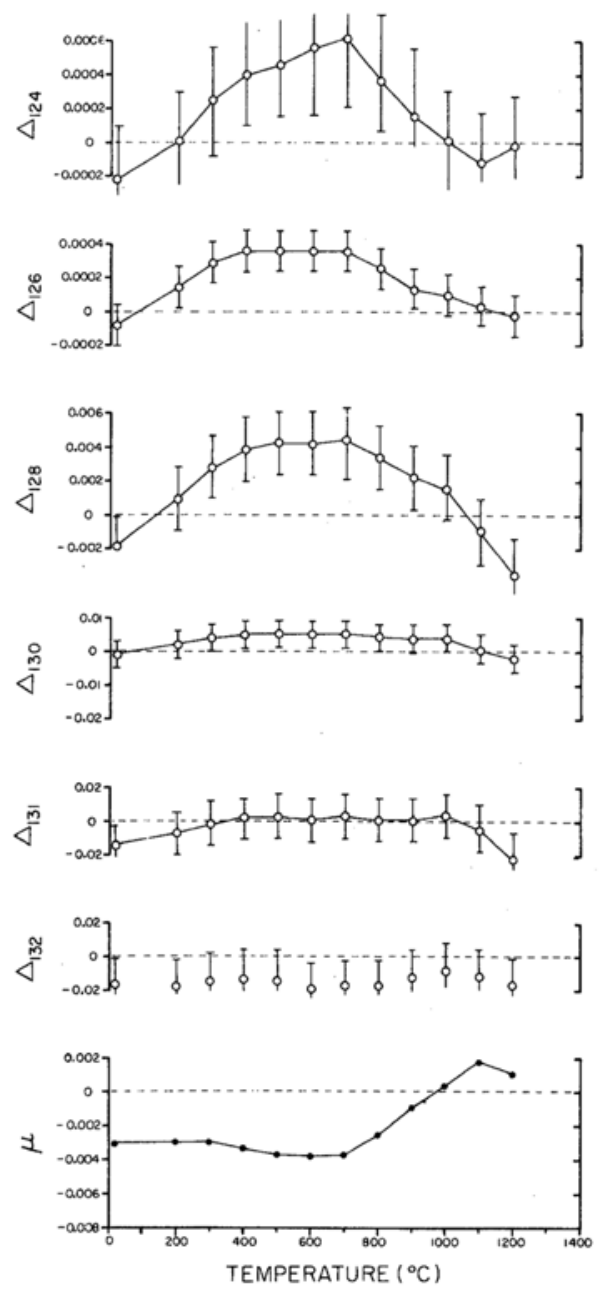

Fig. 11. Values of $\mu$ and $\Delta_{i}$ for the xenon fractions remaining in Renazzo during the stepwise-heating experiments. These values were calculated from the Renazzo data obtained by REYNOLDS and TURNER (1964).

during stepwise-heating experiments. While the values of $\Delta_{131}$ and $\Delta_{132}$ show no significant changes throughout the temperature range between 200 and $1,200^{\circ} \mathrm{C}$, the value of $\mu$ increases steadily above $700^{\circ} \mathrm{C}$ and changes to a positive value at $1,000^{\circ} \mathrm{C}$. This means that while at temperatures below $1,000^{\circ} \mathrm{C}$ the heavier isotopes are systematically enriched relative to AVCC, the opposite is true for the xenon fractions remaining at higher temperatures. It is also interesting to note here that an increase in $\mu$ is accompanied by marked decreases in the values of $\Delta_{124}, \Delta_{126}, \Delta_{128}$ and $\Delta_{130}$.

Figures 12 and 13 show the variations of $\mu$ and $\Delta_{i}$ for the xenon fractions remaining in Mokoia and Allende, respectively, during step-
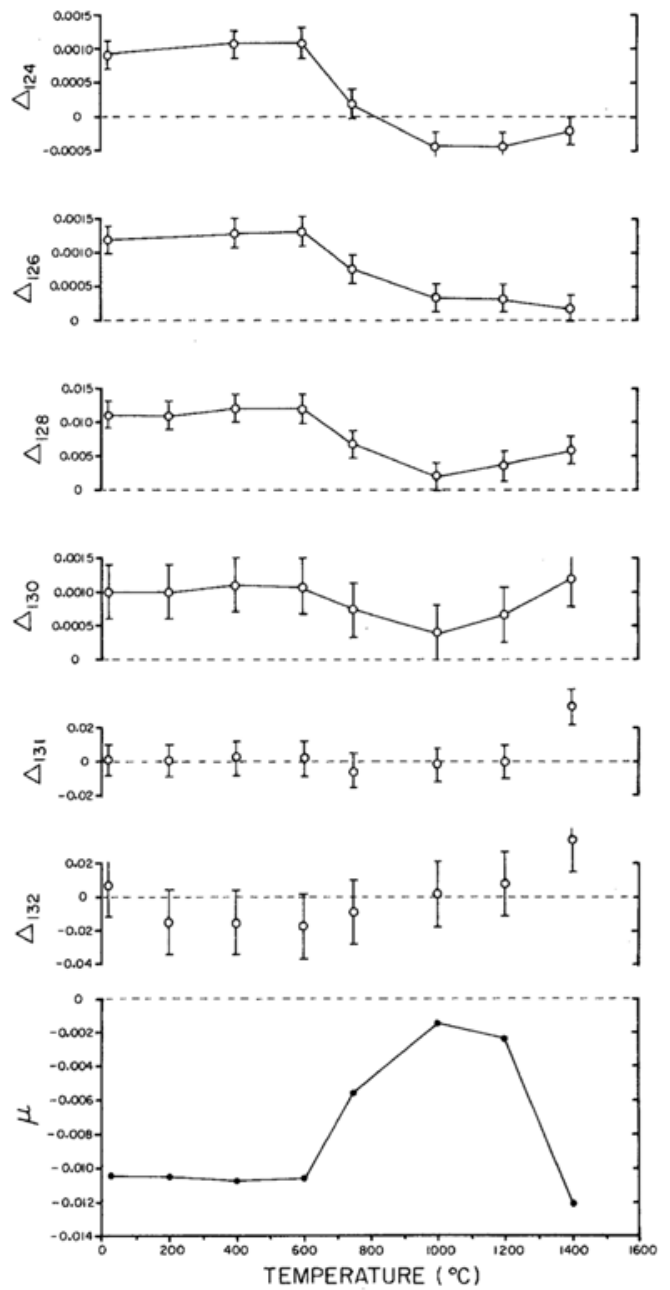

Fig. 12. Values of $\mu$ and $\Delta_{i}$ for the xenon fractions remaining in Mokoia during stepwise-heating experiments. These values were calculated from the data obtained by MANUEL et al. (1972a).

wise-heating experiments. The isotopic composition of the xenon in Murray (KURODA et al., 1974) was used for $V^{i}$ in these calculations. The patterns of variations observed for Mokoia and Allende are quite similar to the pattern observed for Renazzo. The xenon fractions with strange isotopic compositions are released from the meteorites in the temperature range 600 to $1,000^{\circ} \mathrm{C}$, where the values of $\mu$ and $\Delta_{i}$ for the xenon fractions remaining in the meteorites are undergoing marked changes.

The isotopic composition $\left(R^{\mathrm{i}}\right)$ of the strange xenon released from a meteorite at a certain temperature is related to that of the xenon originally present $\left(Q^{\mathrm{i}}\right)$ and that of the xenon being retained by the meteorite at that tem- 

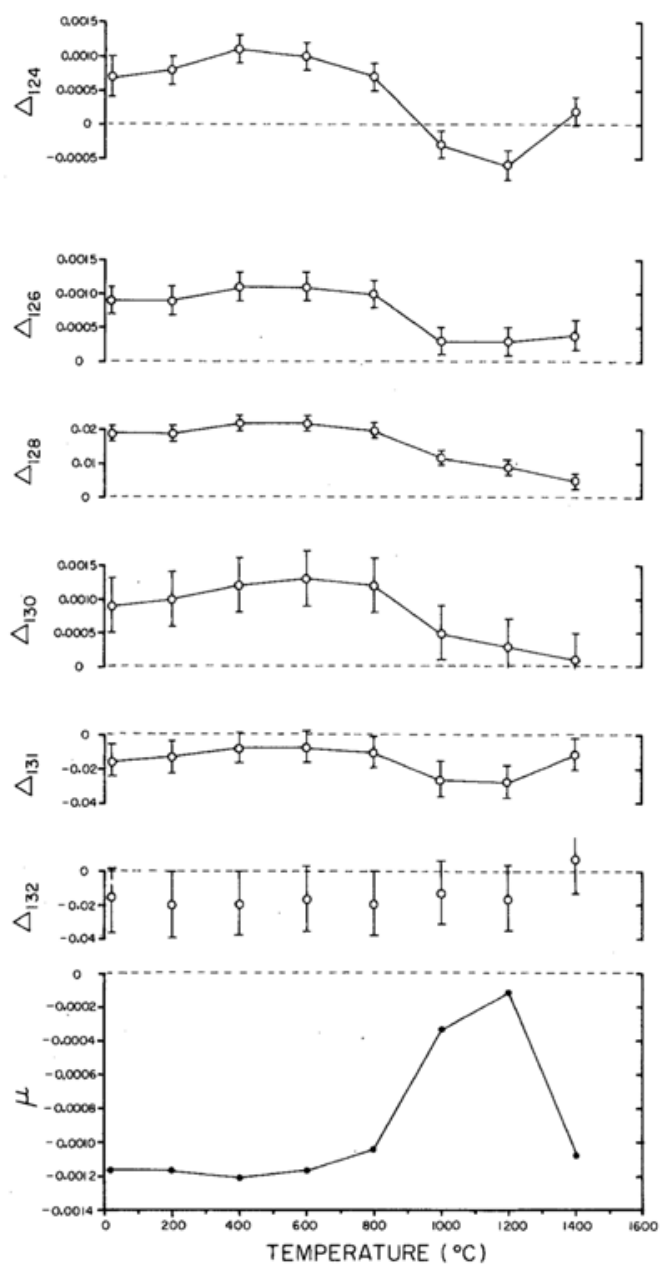

Fig. 13. Values of $\mu$ and $\Delta_{\mathrm{i}}$ for the xenon fractions remaining in Allende during stepwise-heating experiments. These values were calculated from the Mokoia data obtained by MANUEL et al., (1972a).

perature $(P$ i $)$ by the equation

$$
R^{\mathrm{i}}=\frac{1}{\xi_{136}} \cdot Q^{\mathrm{i}}-\frac{\left(1-\xi_{136}\right)}{\xi_{136}} \cdot P^{\mathrm{i}}
$$

where $\xi_{136} /\left(1-\xi_{136}\right)$ represents the ratio of the amount of ${ }^{136} \mathrm{Xe}$ released to that of ${ }^{136} \mathrm{Xe}$ retained by the meteorite (KURODA, 1976a, b).

The values of $P^{\mathrm{i}}$ and $Q^{\mathrm{i}}$ in equation (10) may be written in the form of equation (2) and hence we have

$$
\begin{aligned}
R^{\mathrm{i}} & =\frac{1}{\xi_{136}}\left[\left(V^{\mathrm{i}}+\Delta_{\mathrm{i}}\right)\{1+(136-i) \cdot \mu\}\right. \\
& -\left(1-\xi_{136}\right)\left(V^{\mathrm{i}}+\Delta_{\mathrm{i}}^{\prime}\right)\left\{1+(136-i) \cdot \mu^{\prime}\right\}
\end{aligned}
$$

for the isotopic compositions of the xenon released from the meteorites.

Rearranging equation (11), we have

$$
\begin{aligned}
R^{\mathrm{i}}= & V^{\mathrm{i}} \cdot \frac{1}{\xi_{136}}\left[\nu_{\mathrm{i}}-\left(1-\xi_{136}\right) \cdot \nu_{\mathrm{i}}^{\prime}\right] \\
& +\left[\frac{1}{\xi_{136}} \cdot \Delta_{\mathrm{i}} \cdot \nu_{\mathrm{i}}-\frac{\left(1-\xi_{136}\right)}{\xi_{136}} \cdot \Delta_{\mathrm{i}}^{\prime} \cdot \nu_{\mathrm{i}}^{\prime}\right]
\end{aligned}
$$

or

$$
R^{\mathrm{i}}=V^{\mathrm{i}} \cdot \nu^{\prime \prime}+\left(\delta_{\mathrm{i}}-\delta_{\mathrm{i}}^{\prime}\right)
$$

where $\nu_{\mathrm{i}}=1+(136-i) \cdot \mu$,

$\nu_{\mathrm{i}}^{\prime}=1+(136-i) \cdot \mu^{\prime}$,

$\nu_{\mathrm{i}}^{\prime \prime}=\frac{1}{\xi_{136}}\left\{\nu_{\mathrm{i}}-\left(1-\xi_{136}\right) \cdot \nu_{\mathrm{i}}^{\prime}\right\}$

$\delta_{\mathrm{i}}=\frac{1}{\xi_{136}} \cdot \Delta_{\mathrm{i}} \cdot \nu_{\mathrm{i}}$,

and

$$
\delta_{\mathrm{i}}=\frac{1-\xi_{136}}{\xi_{136}} \cdot \Delta_{\mathrm{i}}^{\prime} \cdot \nu_{\mathrm{i}}^{\prime}
$$

If the values of $\mu$ and $\mu^{\prime}$ are negative and $|\mu|>\left|\mu^{\prime}\right|$, and if the amount of xenon released is much smaller than the amount, which was originally present, or $\xi_{136} \ll 1$, the values of $V^{\mathrm{i}} \cdot \nu_{\mathrm{i}}^{\prime \prime}$ in equation (13) become much smaller than the values of $V^{\mathrm{i}}$ for the light isotopes ${ }^{128} \mathrm{Xe},{ }^{126} \mathrm{Xe}$ and ${ }^{124} \mathrm{Xe}$. At the same time, the values of $\left(\delta_{i}-\delta_{i}^{\prime}\right)$ in equation (13) become comparable to or even greater than the values of $V^{i} \cdot \nu_{i}^{\prime \prime}$, if $\Delta_{i}>\Delta_{i}^{\prime}$. This means that the isotopic composition $\left(R^{\mathrm{i}}\right)$ of the xenon released from the meteorite appears to be severely massfractionated in such a manner that the heavier isotopes are systematically enriched and yet at the same time the relative abundances of the light isotopes ${ }^{128} \mathrm{Xe},{ }^{126} \mathrm{Xe}$ and ${ }^{124} \mathrm{Xe}$ are also progressively enhanced.

Table 3 shows the relationship between the isotopic compositions of the xenon remaining in Renazzo at $700^{\circ} \mathrm{C}$ and $800^{\circ} \mathrm{C}$ and of the xenon released at $800^{\circ} \mathrm{C}$. The isotopic composition of the xenon released from Renazzo at $800^{\circ} \mathrm{C}$ can be calculated from the data shown in Table 3 by the use of equation (13) as shown in Table 4. The values of $\Delta_{i}$ and $\Delta_{i}^{\prime}$ for the xenon fractions remaining in Renazzo at $700^{\circ} \mathrm{C}$ and $800^{\circ} \mathrm{C}$ are very small and hence only approximate values of $\left(\delta_{i}-\delta_{i}^{\prime}\right)$ can be obtained. Nevertheless, the values of $R^{\mathrm{i}}$ thus calculated appear to be in excellent agreement with the observed values of the isotopic composition of xenon released 
Table 3. Relationship between the isotopic compositions of the xenon remaining in Renazzo at $700^{\circ} \mathrm{C}$ and $800^{\circ} \mathrm{C}$ and of the xenon released at $800^{\circ} \mathrm{C}$.

\begin{tabular}{|c|c|c|c|c|c|c|c|}
\hline & \multicolumn{2}{|c|}{ (I) Xenon remaining at $700^{\circ} \mathrm{C}$} & \multicolumn{2}{|c|}{ (II) Xenon remaining at $800^{\circ} \mathrm{C}$} & \multicolumn{2}{|c|}{$\begin{array}{c}(\mathrm{I})-(\mathrm{II})=\text { Xenon released } \\
\text { at } 800^{\circ} \mathrm{C}\end{array}$} & \multirow{2}{*}{$\begin{array}{l}\text { Percentage of } \\
\text { the xenun iso- } \\
\text { topes released } \\
\text { at } 800^{\circ} \mathrm{C} \text { (a) }\end{array}$} \\
\hline & $\begin{array}{c}\left(10^{-12} \mathrm{cc}\right. \\
\mathrm{STP} / \mathrm{g})\end{array}$ & $\begin{array}{c}Q^{\mathrm{i}} \text { (Isotopic } \\
\text { ratio) }\end{array}$ & $\begin{array}{c}\left(10^{-12} \mathrm{cc}\right. \\
\text { STP/g) }\end{array}$ & $\begin{array}{c}P^{\mathrm{i}} \text { (Isotopic } \\
\text { ratio) }\end{array}$ & $\begin{array}{c}\left(10^{-12} \mathrm{cc}\right. \\
\mathrm{STP} / \mathrm{g})\end{array}$ & $\begin{array}{l}R^{1} \text { (Isotopic } \\
\text { ratio) }\end{array}$ & \\
\hline${ }^{124} \mathrm{Xe}$ & 9.8050 & $(0.01429)$ & 8.8079 & $(0.01434)$ & 0.9971 & $(0.01393)$ & $\begin{array}{c}10.169 \\
( \pm 0.203)\end{array}$ \\
\hline${ }^{126} \mathrm{Xe}$ & 8.6421 & $(0.01260)$ & 7.7662 & $(0.01264)$ & 0.8759 & $(0.01223)$ & $\begin{array}{l}10.135 \\
( \pm 0.101)\end{array}$ \\
\hline${ }^{128} \mathrm{Xe}$ & 172.2923 & $(0.2512)$ & 155.0639 & $(0.2524)$ & 17.2284 & $(0.2407)$ & $\begin{array}{c}10.000 \\
( \pm 0.070)\end{array}$ \\
\hline${ }^{130} \mathrm{Xe}$ & 340.673 & $(0.4967)$ & 306.647 & $(0.4991)$ & 34.026 & $(0.4753)$ & $\begin{array}{c}9.988 \\
( \pm 0.040)\end{array}$ \\
\hline${ }^{131} \mathrm{Xe}$ & 1714.6728 & (2.4997) & 1542.5778 & $(2.5109)$ & 172.095 & $(2.4040)$ & $\begin{array}{c}10.037 \\
( \pm 0.030)\end{array}$ \\
\hline${ }^{132} \mathrm{Xe}$ & 2094 & (3.0527) & 1884 & $(3.0666)$ & 210 & $(2.9334)$ & $\begin{array}{c}10.029 \\
( \pm 0.060)\end{array}$ \\
\hline${ }^{134} \mathrm{Xe}$ & 808.8492 & (1.1792) & 726.0672 & (1.1818) & 82.7820 & (1.1564) & $\begin{array}{c}10.235 \\
( \pm 0.082)\end{array}$ \\
\hline${ }^{136} \mathrm{Xe}$ & 685.940 & $(1.0000)$ & 614.353 & $(1.0000)$ & 71.587 & $(1.0000)$ & $\begin{array}{c}10.436 \\
( \pm 0.003)\end{array}$ \\
\hline
\end{tabular}

(a) $\frac{(I)-(I I)}{(I)} \cdot 100=\xi_{\mathrm{i}} \cdot 100$.

Table 4. Isotopic composition of the xenon released from Renazzo at $800^{\circ} \mathrm{C}$.

\begin{tabular}{|c|c|c|c|c|c|c|c|c|c|c|}
\hline$\underset{i}{\text { Mass No. }}$ & $\Delta_{\mathrm{i}}$ & $\nu_{\mathrm{i}}$ & $\delta_{\mathrm{i}}$ & $\Delta_{\mathrm{i}}^{\prime}$ & $\delta_{\mathrm{i}}-\delta_{\mathrm{i}}^{\prime}$ & $V^{\mathrm{i}}$ & $\nu_{\mathrm{i}}^{\prime \prime}$ & $\nu^{\mathrm{i}} \cdot \nu_{\mathrm{i}}^{\prime \prime}$ & $\begin{array}{c}\text { Isotopic co } \\
R \mathrm{i} \\
\text { (Calculated) } \\
\end{array}$ & $\begin{array}{c}\text { mposition } \\
R^{\mathrm{i}} \\
\text { (Experimental) } \\
\end{array}$ \\
\hline 124 & $\begin{array}{r}0.00051 \\
\pm 0.00027\end{array}$ & 0.95556 & $\begin{array}{r}0.0047 \\
\pm 0.0025\end{array}$ & $\begin{array}{r}0.00037 \\
\pm 0.00027\end{array}$ & $\begin{array}{r}0.0016 \\
\pm 0.0025\end{array}$ & 0.01442 & 0.84266 & 0.01215 & $\begin{array}{c}0.01375 \\
\pm 0.0025\end{array}$ & 0.01393 \\
\hline 126 & $\begin{array}{r}0.00036 \\
\pm 0.00012\end{array}$ & 0.96296 & $\begin{array}{r}0.0033 \\
\pm 0.0011\end{array}$ & $\begin{array}{r}0.00026 \\
\pm 0.00012\end{array}$ & $\begin{array}{r}0.0011 \\
\pm 0.0011\end{array}$ & 0.01271 & 0.86900 & 0.01105 & $\begin{array}{l}0.01215 \\
\pm 0.0011\end{array}$ & 0.01223 \\
\hline 128 & $\begin{array}{r}0.0044 \\
\pm 0.0019\end{array}$ & 0.97038 & $\begin{array}{c}0.0409 \\
\pm 0.018\end{array}$ & $\begin{array}{r}0.0034 \\
\pm 0.0019\end{array}$ & $\begin{array}{c}0.0123 \\
\pm 0.018\end{array}$ & 0.2543 & 0.89526 & 0.2277 & $\begin{array}{r}0.240 \\
\pm 0.018\end{array}$ & 0.2407 \\
\hline 130 & $\begin{array}{r}0.0054 \\
\pm 0.0039\end{array}$ & 0.97778 & $\begin{array}{c}0.0506 \\
\pm 0.037\end{array}$ & $\begin{array}{r}0.0045 \\
\pm 0.0039\end{array}$ & $\begin{array}{c}0.0126 \\
\pm 0.037\end{array}$ & 0.5025 & 0.92142 & 0.4630 & $\begin{array}{r}0.476 \\
\pm 0.037\end{array}$ & 0.4753 \\
\hline 131 & $\begin{array}{c}0.0038 \\
\pm 0.013\end{array}$ & 0.98149 & $\begin{array}{c}0.0357 \\
\pm 0.122\end{array}$ & $\begin{array}{c}0.0011 \\
\pm 0.013\end{array}$ & $\begin{array}{r}0.026 \\
\pm 0.122\end{array}$ & 2.543 & 0.93455 & 2.377 & $\begin{array}{r}2.403 \\
\pm 0.122\end{array}$ & 2.404 \\
\hline $132=$ & $\begin{array}{l}-0.0171 \\
\pm 0.016\end{array}$ & 0.99259 & $\begin{array}{l}-0.163 \\
\pm 0.152\end{array}$ & $\begin{array}{l}-0.0169 \\
\pm 0.016\end{array}$ & - & 3.116 & 0.94768 & 2.953 & 2.953 & 2.933 \\
\hline 134 & - & - & - & - & - & 1.188 & 0.97384 & 1.157 & 1.157 & 1.1564 \\
\hline 136 & - & - & - & - & - & 1.0000 & 1.00000 & 1.000 & 1.000 & 1.0000 \\
\hline
\end{tabular}

from Renazzo at $800^{\circ} \mathrm{C}$ (REYNOLDS and TURNER, 1964).

Tables 5 and 6 show the results of similar calculations for the xenon released from Mokoia at $750^{\circ} \mathrm{C}$ (MANUEL et al., 1972a). The agreement between the calculated and observed values of $R^{\mathrm{i}}$ is again excellent. Tables 7 and 8 show the results of similar calculations for the xenon released from Allende at $800^{\circ} \mathrm{C}$ (MANuel et al., 1972a). It is interesting to note here that the amount of xenon released was quite small in this case and hence $\xi_{\mathrm{i}} \ll 1$. The isotopic com- position of the xenon released from Allende at $800^{\circ} \mathrm{C}$ thus appears as if it contains a severely mass fractionated AVCC xenon with a negative value of $V^{i} \cdot \nu_{\mathrm{i}}^{\prime \prime}$ for $i=124$, while the values of $\left(\delta_{\mathrm{i}}-\delta_{\mathrm{i}}^{\prime}\right)$ for the light isotopes ${ }^{128} \mathrm{Xe},{ }^{126} \mathrm{Xr}$ and ${ }^{124} \mathrm{Xe}$ are all greater than the values of $V^{i} \cdot \nu^{\prime \prime}$. It seems that the agreement between the calculated and observed values of $R^{\mathrm{i}}$ is quite reasonable, considering the fact that large uncertainties are associated with the calculations of the values of $\left(\delta_{i}-\delta_{i}^{\prime}\right)$.

The isotopic compositions of the strange 
Table 5. Relationship between the isotopic compositions of the xenon fractions remaining in Mokoia at $600^{\circ} \mathrm{C}$ and $750^{\circ} \mathrm{C}$, and of the xenon fraction released at $750^{\circ} \mathrm{C}$.

\begin{tabular}{|c|c|c|c|c|c|c|c|}
\hline & \multicolumn{2}{|c|}{ (I) Xenon remaining at $600^{\circ} \mathrm{C}$} & \multicolumn{2}{|c|}{ (II) Xenon remaining at $750^{\circ} \mathrm{C}$} & \multicolumn{2}{|c|}{$\begin{array}{l}\text { (I)-(II) }=\text { Xenon released } \\
\text { at } 750^{\circ} \mathrm{C}\end{array}$} & \multirow{2}{*}{$\begin{array}{l}\text { Percentage of } \\
\text { the xenon iso- } \\
\text { topes released } \\
\text { at } 750^{\circ} \mathrm{C} \text { (a) }\end{array}$} \\
\hline & $\begin{array}{c}\left(10^{-12} \mathrm{cc}\right. \\
\mathrm{STP} / \mathrm{g})\end{array}$ & $Q^{\mathrm{i}} \begin{array}{c}\text { (Isotopic } \\
\text { ratio) }\end{array}$ & $\begin{array}{c}\left(10^{-12} \mathrm{cc}\right. \\
\mathrm{STP} / \mathrm{g})\end{array}$ & $\begin{array}{c}P^{\mathrm{i}} \text { (Isotopic } \\
\text { ratio) }\end{array}$ & $\begin{array}{c}\left(10^{-12} \mathrm{cc}\right. \\
\text { STP/g) }\end{array}$ & $R^{\mathrm{i}} \begin{array}{c}\text { (Isotopic } \\
\text { ratio) }\end{array}$ & \\
\hline${ }^{124} \mathrm{Xe}$ & 11.8094 & $(0.01411)$ & 10.6472 & $(0.01424)$ & 1.1622 & $(0.0130)$ & $9.841( \pm 0.151)$ \\
\hline${ }^{126} \mathrm{Xe}$ & 10.8102 & $(0.01292)$ & 9.8178 & $(0.01313)$ & 0.9923 & $(0.0111)$ & $9.179( \pm 0.165)$ \\
\hline${ }^{128} \mathrm{Xe}$ & 206.7284 & $(0.2470)$ & 188.9378 & $(0.2527)$ & 17.7906 & $(0.199)$ & $8.606( \pm 0.086)$ \\
\hline${ }^{130} \mathrm{Xe}$ & 405.3342 & $(0.4843)$ & 371.094 & $(0.4964)$ & 34.2402 & $(0.446)$ & $8.447( \pm 0.066)$ \\
\hline${ }^{131} \mathrm{Xe}$ & 2040.8138 & (2.4382) & 1864.7852 & (2.4944) & 176.0286 & (1.969) & $8.625( \pm 0.066)$ \\
\hline${ }^{132} \mathrm{Xe}$ & 2488.9026 & (2.9736) & 2275.0578 & $(3.0431)$ & 213.8448 & (2.392) & $8.592( \pm 0.039)$ \\
\hline${ }^{134} \mathrm{Xe}$ & 975.6020 & (1.1656) & 880.2122 & (1.1774) & 95.3898 & (1.067) & $9.778( \pm 0.083)$ \\
\hline${ }^{136} \mathrm{Xe}$ & 837. & $(1.0000)$ & 747.6 & $(1.0000)$ & 89.4 & $(1.0000)$ & $10.681( \pm 0.049)$ \\
\hline
\end{tabular}

(a) $\frac{(I)-(I I)}{(I)} \cdot 100=\xi_{i} \cdot 100$

Table 6. Isotopic composition of the xenon released from Mokoia at $750^{\circ} \mathrm{C}$.

\begin{tabular}{|c|c|c|c|c|c|c|c|c|c|c|}
\hline Mass No. & $\Delta_{\mathrm{i}}$ & $\nu_{\mathrm{i}}$ & $\delta_{\mathrm{i}}$ & $\Delta_{\mathrm{i}}^{\prime}$ & $\delta_{\mathrm{i}}-\delta_{\mathrm{i}}^{\prime}$ & $V^{\mathrm{i}}$ & $\nu_{\mathrm{i}}^{\prime \prime}$ & $V^{\mathrm{i}} \cdot \nu_{\mathrm{i}}^{\prime \prime}$ & $\begin{array}{c}\text { Isotopic ce } \\
R^{\mathrm{i}} \\
\text { (Calculated) }\end{array}$ & $\begin{array}{c}\text { mposition } \\
R^{\mathrm{i}} \\
\text { (Experimental) }\end{array}$ \\
\hline 124 & $\begin{array}{c}0.00108 \\
\pm 0.0002\end{array}$ & 0.87304 & $\begin{array}{r}0.0088 \\
\pm 0.0016\end{array}$ & $\begin{array}{l}0.00019 \\
\pm 0.0002\end{array}$ & $\begin{array}{r}0.0073 \\
\pm 0.0016\end{array}$ & 0.01508 & 0.37559 & 0.00566 & $\begin{array}{r}0.0130 \\
\pm 0.0016\end{array}$ & 0.0130 \\
\hline 126 & $\begin{array}{c}0.00131 \\
\pm 0.0002\end{array}$ & 0.89420 & $\begin{array}{r}0.0110 \\
\pm 0.0017\end{array}$ & $\begin{array}{r}0.00077 \\
\pm 0.0002\end{array}$ & $\begin{array}{r}0.0049 \\
\pm 0.0017\end{array}$ & 0.01314 & 0.48001 & 0.00631 & $\begin{array}{r}0.0112 \\
\pm 0.0017\end{array}$ & 0.0111 \\
\hline 128 & $\begin{array}{l}0.0120 \\
\pm 0.002\end{array}$ & 0.91536 & $\begin{array}{r}0.103 \\
\pm 0.017\end{array}$ & $\begin{array}{c}0.0068 \\
\pm 0.002\end{array}$ & $\begin{array}{r}0.049 \\
\pm 0.017\end{array}$ & 0.2578 & 0.58403 & 0.1506 & $\begin{array}{r}0.200 \\
\pm 0.017\end{array}$ & 0.199 \\
\hline 130 & $\begin{array}{r}0.0107 \\
\pm 0.002\end{array}$ & 0.93652 & $\begin{array}{r}0.094 \\
\pm 0.035\end{array}$ & $\begin{array}{c}0.0073 \\
\pm 0.002\end{array}$ & $\begin{array}{r}0.035 \\
\pm 0.035\end{array}$ & 0.5064 & 0.68795 & 0.3484 & $\begin{array}{r}0.383 \\
\pm 0.035\end{array}$ & 0.383 \\
\hline 131 & $\begin{array}{c}0.0024 \\
\pm 0.018\end{array}$ & 0.94710 & $\begin{array}{l}0.0212 \\
\pm 0.16\end{array}$ & $\begin{array}{l}-0.0054 \\
\pm 0.18\end{array}$ & $\begin{array}{l}0.0642 \\
\pm 0.16\end{array}$ & 2.5720 & 0.74000 & 1.903 & $\begin{aligned} & 1.967 \\
& \pm 0.16\end{aligned}$ & 1.969 \\
\hline 132 & $\begin{array}{l}-0.0169 \\
\pm 0.019\end{array}$ & 0.95768 & $\begin{array}{l}-0.1515 \\
\pm 0.17\end{array}$ & $\begin{array}{l}-0.0088 \\
\pm 0.019\end{array}$ & $\begin{array}{l}-0.0796 \\
\pm 0.17\end{array}$ & 3.1220 & 0.79206 & 2.473 & $\begin{aligned} & 2.393 \\
& \pm 0.17\end{aligned}$ & 2.392 \\
\hline 134 & - & - & - & - & - & 1.1908 & 0.89598 & 1.067 & 1.067 & 1.067 \\
\hline 136 & - & - & - & - & - & 1.0000 & 1.00000 & 1.000 & 1.000 & 1.000 \\
\hline
\end{tabular}

Table 7. Relationship between the isotopic compositions of the xenon remaining in Allende at $600^{\circ} \mathrm{Cand} 800^{\circ} \mathrm{C}$ and of the xenon released at $800^{\circ} \mathrm{C}$.

\begin{tabular}{|c|c|c|c|c|c|c|c|}
\hline & \multicolumn{2}{|c|}{ (I) Xenon remaining at $600^{\circ} \mathrm{C}$} & \multicolumn{2}{|c|}{ (II) Xenon remaining at $800^{\circ} \mathrm{C}$} & \multicolumn{2}{|c|}{$\begin{array}{c}(\mathrm{I})-(\mathrm{II})=\text { Xenon released } \\
\text { at } 800^{\circ} \mathrm{C}\end{array}$} & \multirow{2}{*}{$\begin{array}{l}\text { Percentage of } \\
\text { the xenon iso- } \\
\text { topes released } \\
\text { at } 800^{\circ} \mathrm{C} \text { (a) }\end{array}$} \\
\hline & $\begin{array}{c}\left(10^{-12} \mathrm{cc}\right. \\
\mathrm{STP} / \mathrm{g})\end{array}$ & $Q^{\mathrm{i}} \begin{array}{c}\text { (Isotopic } \\
\text { ratio) }\end{array}$ & $\begin{array}{r}\left(10^{-12} \mathrm{cc}\right. \\
\mathrm{STP} / \mathrm{g})\end{array}$ & $\begin{array}{c}P \mathrm{i} \text { (Isotopic } \\
\text { ratio) }\end{array}$ & $\begin{array}{c}\left(10^{-12} \mathrm{cc}\right. \\
\mathrm{STP} / \mathrm{g})\end{array}$ & $\begin{array}{c}R^{\mathrm{i}} \text { (Isotopic } \\
\text { ratio) }\end{array}$ & \\
\hline${ }^{124} \mathrm{Xe}$ & 7.0003 & $(0.0139)$ & 6.8969 & $(0.0139)$ & 0.1035 & $(0.0121)$ & $1.471( \pm 0.049)$ \\
\hline${ }^{126} \mathrm{Xe}$ & 6.3638 & $(0.0126)$ & 6.2826 & $(0.0127)$ & 0.0813 & $(0.0095)$ & $1.273( \pm 0.040)$ \\
\hline${ }^{128} \mathrm{Xe}$ & 128.128 & $(0.2540)$ & 126.640 & $(0.2554)$ & 1.488 & $(0.174)$ & $1.161( \pm 0.027)$ \\
\hline${ }^{130} \mathrm{Xe}$ & 243.61 & $(0.4830)$ & 240.75 & $(0.4856)$ & 2.86 & $(0.334)$ & $1.174( \pm 0.021)$ \\
\hline${ }^{131} \mathrm{Xe}$ & 1218.59 & $(2.416)$ & 1203.78 & $(2.428)$ & 14.81 & (1.732) & $1.215( \pm 0.019)$ \\
\hline${ }^{132} \mathrm{Xe}$ & 1492.69 & (2.9596) & 1474.38 & $(2.974)$ & 18.31 & $(2.142)$ & $1.226( \pm 0.016)$ \\
\hline${ }^{134} \mathrm{Xe}$ & 586.75 & (1.1634) & 578.04 & (1.1659) & 8.71 & (1.019) & $1.484( \pm 0.023)$ \\
\hline${ }^{136} \mathrm{Xe}$ & 504.35 & $(1.000)$ & 495.8 & $(1.000)$ & 8.55 & (1.000) & $1.695( \pm 0.022)$ \\
\hline
\end{tabular}

(a) $\frac{(I)-(I I)}{(I)} \cdot 100=\xi_{\mathrm{i}} \cdot 100$ 
Table 8. Isotopic composition of the xenon released from Allende at $800^{\circ} \mathrm{C}$.

\begin{tabular}{|c|c|c|c|c|c|c|c|c|c|c|}
\hline$\underset{\mathrm{i}}{\text { Mass No. }}$ & $\Delta_{\mathrm{i}}$ & $\nu_{\mathrm{i}}$ & $\delta_{\mathrm{i}}$ & $\Delta_{\mathrm{i}}^{\prime}$ & $\delta_{\mathrm{i}}-\delta_{\mathrm{i}}^{\prime}$ & $V^{\mathrm{i}}$ & $\nu_{\mathrm{i}}^{\prime \prime}$ & $V \mathrm{i} \cdot \nu_{\mathrm{i}}^{\prime \prime}$ & $\begin{array}{c}\text { Isotopic c } \\
R^{\mathrm{i}} \\
\text { (Calculated) }\end{array}$ & $\begin{array}{l}\text { mposition } \\
\quad R^{\mathrm{i}} \\
\text { (Experimental) }\end{array}$ \\
\hline 124 & $\begin{array}{c}0.00104 \\
\pm 0.0002\end{array}$ & 0.85996 & $\begin{array}{r}0.0528 \\
\pm 0.0102\end{array}$ & $\begin{array}{l}0.00068 \\
\pm 0.0002\end{array}$ & $\begin{array}{r}0.0183 \\
\pm 0.0102\end{array}$ & 0.01508 & -0.01652 & -0.000249 & $\begin{array}{r}0.018 \\
\pm 0.010\end{array}$ & 0.0121 \\
\hline 126 & $\begin{array}{c}0.00113 \\
\pm 0.0002\end{array}$ & 0.88330 & $\begin{array}{r}0.0589 \\
\pm 0.0104\end{array}$ & $\begin{array}{l}0.00100 \\
\pm 0.0002\end{array}$ & $\begin{array}{r}0.0070 \\
\pm 0.0104\end{array}$ & 0.01314 & 0.15280 & 0.00201 & $\begin{array}{r}0.009 \\
\pm 0.010\end{array}$ & 0.0095 \\
\hline 128 & $\begin{array}{l}0.0224 \\
\pm 0.002\end{array}$ & 0.90664 & $\begin{array}{r}1.198 \\
\pm 0.107\end{array}$ & $\begin{array}{l}0.0201 \\
\pm 0.002\end{array}$ & $\begin{array}{r}0.130 \\
\pm 0.107\end{array}$ & 0.2578 & 0.32212 & 0.08304 & $\begin{array}{r}0.213 \\
\pm 0.107\end{array}$ & 0.174 \\
\hline 130 & $\begin{array}{l}0.0130 \\
\pm 0.004\end{array}$ & 0.92298 & $\begin{array}{l}0.7079 \\
\pm 0.218\end{array}$ & $\begin{array}{r}0.0117 \\
\pm 0.004\end{array}$ & $\begin{array}{r}0.072 \\
\pm 0.218\end{array}$ & 0.5064 & 0.49145 & 0.2489 & $\begin{array}{r}0.321 \\
\pm 0.218\end{array}$ & 0.334 \\
\hline 131 & $\begin{array}{l}-0.007 \\
\pm 0.009\end{array}$ & 0.94165 & $\begin{array}{l}-0.389 \\
\pm 0.500\end{array}$ & $\begin{array}{l}-0.010 \\
\pm 0.009\end{array}$ & $\begin{array}{r}0.161 \\
\pm 0.500\end{array}$ & 2.5720 & 0.57640 & 1.483 & $\begin{array}{r}1.644 \\
\pm 0.500\end{array}$ & 1.732 \\
\hline 132 & $\begin{array}{l}-0.017 \\
\pm 0.019\end{array}$ & 0.95332 & $\begin{array}{l}-0.956 \\
\pm 1.06\end{array}$ & $\begin{array}{l}-0.019 \\
\pm 0.019\end{array}$ & $\begin{array}{c}0.104 \\
\pm 1.06\end{array}$ & 3.1220 & 0.66077 & 2.063 & $\begin{array}{r}2.167 \\
\pm 1.06\end{array}$ & 2.142 \\
\hline 134 & - & - & - & - & - & 1.1908 & 0.83068 & 0.989 & 0.989 & 1.019 \\
\hline 136 & - & - & - & - & - & 1.0000 & 1.00000 & 1.000 & 1.000 & 1.000 \\
\hline
\end{tabular}

Table 9. Relationship between the isotopic compositions of the xenon in Allende 3CS1 and Allende 3CS2.

\begin{tabular}{|c|c|c|c|c|c|c|c|}
\hline$\underset{\text { i }}{\text { Mass No. }}$ & $\begin{array}{l}\text { (I) Xenon in } \\
\left(10^{-10} \mathrm{cc}\right. \\
\mathrm{STP} / \mathrm{g})\end{array}$ & $\begin{array}{l}\text { Allende } 3 \text { CS1 } \\
Q^{\mathrm{i}} \text { (Isotopic } \\
\text { ratio) }\end{array}$ & $\begin{array}{r}\text { (II) Xenor } \\
\text { duri } \\
\left(10^{-10} \mathrm{cc}\right. \\
\mathrm{STP} / \mathrm{g})\end{array}$ & $\begin{array}{l}\text { which escaped } \\
\text { etching } \\
P \text { i (Isotopic } \\
\text { ratio) }\end{array}$ & $\begin{array}{c}(\mathrm{III})=(\mathrm{I})-( \\
\text { in Alle } \\
\left(10^{-10} \mathrm{cc}\right. \\
\text { STP/g) }\end{array}$ & $\begin{array}{l}\text { Xenon found } \\
\text { e } 3 \subset S 2 \\
R \text { i (isotopic } \\
\text { ratio) }\end{array}$ & $\begin{array}{l}\text { Percentages of } \\
\text { the xenon isotopes } \\
\text { which were not lost } \\
\text { during etching (a) }\end{array}$ \\
\hline${ }^{124} \mathrm{Xe}$ & 9.3942 & $(0.014000)$ & 7.80518 & $(0.01425)$ & 1.58902 & $(0.01293)$ & $16.915( \pm 0.250)$ \\
\hline${ }^{126} \mathrm{Xe}$ & 8.3030 & $(0.01238)$ & 7.0651 & $(0.01289)$ & 1.23788 & $(0.01007)$ & $14.909( \pm 0.255)$ \\
\hline${ }^{128} \mathrm{Xe}$ & 162.430 & $(0.2425)$ & 140.113 & $(0.2558)$ & 22.3170 & $(0.1815)$ & $13.740( \pm 0.079)$ \\
\hline${ }^{130} \mathrm{Xe}$ & 320.614 & $(0.4780)$ & 279.4372 & $(0.5101)$ & 41.1768 & (0.3349) & $12.843( \pm 0.080)$ \\
\hline${ }^{131} \mathrm{Xe}$ & 1624.30 & $(2.4215)$ & 1409.515 & (2.5728) & 214.785 & (1.7471) & $13.223( \pm 0.071)$ \\
\hline${ }^{132} \mathrm{Xe}$ & 1984 & $(2.9577)$ & 1726 & (3.1505) & 258 & (2.0986) & $13.004( \pm 0.060)$ \\
\hline${ }^{134} \mathrm{Xe}$ & 778.323 & (1.1603) & 653.632 & (1.1931) & 124.691 & (1.0143) & $16.020( \pm 0.060)$ \\
\hline${ }^{136} \mathrm{Xe}$ & 670.790 & $(1.0000)$ & 547.853 & $(1.0000)$ & 122.937 & $(1.0000)$ & $18.327( \pm 0.085)$ \\
\hline
\end{tabular}

$$
\text { (a) } \frac{(I)-(I I)}{(I)} \cdot 100=\xi_{\mathrm{i}} \cdot 100
$$

xenon obtained by LEwIS et al. (1975) from Allende in acid-etching experiments are similar to that of the xenon released from the meteorite at $800^{\circ} \mathrm{C}$. Tables 9 and 11 show the relationships between the isotopic compositions of the xenon in Allende 3CS1, 3CS2 and 3CS4. Tables 10 and 12 show that the isotopic compositions $\left(R^{\mathrm{i}}\right)$ of the xenon found in $3 \mathrm{CS} 2$ and and $3 \mathrm{CS} 4$, respectively, calculated by equation (13) also agree with experimental values reasonably well.

\section{CONCLUSION}

It seems that the existing xenon isotope data can be explained satisfactorily by the theory that the xenon isotopic ratios are altered by a combined effect of mass-fractionation, neutron capture and cosmic-ray irradiation processes, which took place during the early history of the solar system (KURODA, 1971; KURODA et al., 1974, 1975; Kuroda, 1967a, b). The carbonaceous chondrites appear to contain three different types of xenon: (a) the atmospheric xenon, most of which is released from the meteorites at temperatures below $400^{\circ} \mathrm{C}$, (b) the xenon, which contains excess light isotopes relative to the AVCC xenon and which escapes from the meteorites in the temperature range $600^{\circ}$ to $1,000^{\circ} \mathrm{C}$, and (c) the AVCC-type xenon, which is released usually at higher temperatures. In the meteorites such as Renazzo, Mokoia and Allende, the xenon components (a), (b) and (c) are bound to the mineral lattices with suc- 
Table 10 Isotopic composition of the xenon in Allende 3CS2. The values of $\Delta_{i}, v_{i}$ and $\delta_{i}$ were calculated from the isotopic composition of the xenon in $3 C S 1$ and the values of $\Delta_{i}^{\prime}$ and $\delta_{i}^{\prime}$ were calculated from that of the xenon, which escaped from 3CS1 during etching (see Table 9).

\begin{tabular}{|c|c|c|c|c|c|c|c|c|c|c|}
\hline $\begin{array}{c}\text { Mass No. } \\
\quad i\end{array}$ & $\Delta_{\mathrm{i}}$ & $\nu_{\mathrm{i}}$ & $\delta_{\mathrm{i}}$ & $\Delta_{\mathrm{i}}^{\prime}$ & $\delta_{i}^{\prime}$ & $V^{\mathrm{i}}$ & $\nu_{\mathrm{i}}^{\prime \prime}$ & $V^{\mathrm{i} \cdot \nu_{\mathrm{i}}^{\prime \prime}}$ & \multicolumn{2}{|c|}{$\begin{array}{c}\text { Isotopic composition of the } \\
\text { xenon in Allende 3CS2 } \\
R^{\mathrm{i}} \quad R^{\mathrm{i}} \\
\text { (Calculated) (Experimental) }\end{array}$} \\
\hline 124 & $\begin{array}{c}0.00160 \\
\pm 0.0005\end{array}$ & 0.86008 & $\begin{array}{r}0.0117 \\
\pm 0.0037\end{array}$ & $\begin{array}{l}-0.00054 \\
\pm 0.0005\end{array}$ & $\sim 0$ & 0.01442 & 0.12173 & 0.0018 & $\begin{array}{r}0.0135 \\
\pm 0.0037\end{array}$ & $\begin{array}{r}0.0129 \\
\pm 0.0002\end{array}$ \\
\hline 126 & $\begin{array}{l}0.00115 \\
\pm 0.0003\end{array}$ & 0.88340 & $\begin{array}{r}0.0087 \\
\pm 0.0022\end{array}$ & $\begin{array}{l}-0.0009 \\
\pm 0.0003\end{array}$ & $\sim 0$ & 0.01271 & 0.26813 & 0.0034 & $\begin{array}{c}0.0121 \\
\pm 0.022\end{array}$ & $\begin{array}{r}0.0101 \\
\pm 0.0002\end{array}$ \\
\hline 128 & $\begin{array}{r}0.0120 \\
\pm 0.0024\end{array}$ & 0.90672 & $\begin{array}{r}0.093 \\
\pm 0.019\end{array}$ & $\begin{array}{l}-0.00287 \\
\pm 0.0024\end{array}$ & $\sim 0$ & 0.2543 & 0.41452 & 0.1054 & $\begin{array}{c}0.1984 \\
\pm 0.019\end{array}$ & $\begin{array}{r}0.1815 \\
\pm 0.0010\end{array}$ \\
\hline 130 & $\begin{array}{l}0.0107 \\
\pm 0.005\end{array}$ & 0.93004 & $\begin{array}{r}0.085 \\
\pm 0.039\end{array}$ & $\begin{array}{l}+0.00113 \\
\pm 0.005\end{array}$ & $\sim 0$ & 0.5025 & 0.56086 & 0.2818 & $\begin{array}{r}0.367 \\
\pm 0.005\end{array}$ & $\begin{array}{r}0.335 \\
\pm 0.002\end{array}$ \\
\hline 131 & $\begin{array}{c}0.0268 \\
\pm 0.002\end{array}$ & 0.94170 & $\begin{array}{r}0.216 \\
\pm 0.016\end{array}$ & $\begin{array}{l}+0.0025 \\
\pm 0.002\end{array}$ & $\sim 0$ & 2.543 & 0.63403 & 1.612 & $\begin{array}{r}1.828 \\
\pm 0.016\end{array}$ & $\begin{array}{r}1.748 \\
\pm 0.009\end{array}$ \\
\hline 132 & $\begin{array}{l}-0.013 \\
\pm 0.020\end{array}$ & 0.95336 & $\begin{array}{l}-0.106 \\
\pm 0.163\end{array}$ & $\begin{array}{l}+0.0078 \\
\pm 0.020\end{array}$ & $\sim 0$ & 3.116 & 0.70726 & 2.204 & $\begin{array}{r}2.098 \\
\pm 0.163\end{array}$ & $\begin{array}{r}2.099 \\
\pm 0.020\end{array}$ \\
\hline 134 & - & - & - & - & - & 1.188 & 0.85360 & 1.014 & $\begin{array}{r}1.014 \\
\pm 0.050\end{array}$ & $\begin{array}{r}1.014 \\
\pm 0.004\end{array}$ \\
\hline 136 & - & - & - & - & - & 1.000 & 1.00000 & 1.000 & 1.000 & 1.000 \\
\hline
\end{tabular}

Table 11. Relationship between the isotopic compositions of the xenon in Allende 3CS1 and Allende 3CS4.

\begin{tabular}{|c|c|c|c|c|c|c|c|}
\hline \multirow{2}{*}{$\begin{array}{l}\text { Mass No. } \\
\text { i }\end{array}$} & \multicolumn{2}{|c|}{ (I) Xenon in Allende 3CS1 } & \multicolumn{2}{|c|}{$\begin{array}{l}\text { (II) Xenon which escaped } \\
\text { during etching }\end{array}$} & \multicolumn{2}{|c|}{$\begin{array}{l}\text { (III) }=\text { (I)-(II) Xenon found } \\
\text { in Allende 3CS4 }\end{array}$} & \multirow{2}{*}{$\begin{array}{l}\text { Percentage of the } \\
\text { xenon isotopes } \\
\text { which were not lost } \\
\text { during etching (a) }\end{array}$} \\
\hline & $\begin{array}{c}\left(10^{-10} \mathrm{cc}\right. \\
\text { STP/g) }\end{array}$ & $\begin{array}{l}Q^{\mathrm{i}} \text { (Isotopic } \\
\text { ratio) }\end{array}$ & $\begin{array}{c}\left(10^{-10} \mathrm{cc}\right. \\
\text { STP/g })\end{array}$ & $\begin{array}{c}P \mathrm{i} \text { (Isotopic } \\
\text { ratio) }\end{array}$ & $\begin{array}{c}\left(10^{-10} \mathrm{cc}\right. \\
\mathrm{STP} / \mathrm{g})\end{array}$ & $\begin{array}{c}R_{\mathrm{i}}^{\mathrm{i}} \text { (Isotopic } \\
\text { ratio) }\end{array}$ & \\
\hline${ }^{124} \mathrm{Xe}$ & 9.3942 & $(0.01400)$ & 8.4154 & $(0.01420)$ & 0.97883 & $(0.01247)$ & $10.420( \pm 0.229)$ \\
\hline${ }^{126} \mathrm{Xe}$ & 8.3030 & $(0.01238)$ & 7.6473 & $(0.01291)$ & 0.65570 & $(0.008351)$ & $7.897( \pm 0.373)$ \\
\hline${ }^{128} \mathrm{Xe}$ & 162.430 & $(0.2425)$ & 150.6086 & $(0.2542)$ & 11.8214 & $(0.1505)$ & $7.278( \pm 0.091)$ \\
\hline${ }^{130} \mathrm{Xe}$ & 320.614 & $(0.4780)$ & 299.287 & $(0.5052)$ & 21.3270 & $(0.2716)$ & $6.652( \pm 0.059)$ \\
\hline${ }^{131} \mathrm{Xe}$ & 1624.30 & (2.4215) & 1511.70 & $(2.5520)$ & 112.5994 & (1.4340) & $6.932( \pm 0.060)$ \\
\hline${ }^{132} \mathrm{Xe}$ & 1984 & (2.9577) & 1849.36 & (3.1220) & 134.64 & (1.7147) & $6.786( \pm 0.055)$ \\
\hline${ }^{134} \mathrm{Xe}$ & 788.323 & (1.1603) & 702.9785 & (1.1867) & 75.3445 & $(0.9595)$ & $9.680( \pm 0.071)$ \\
\hline${ }^{136} \mathrm{Xe}$ & 670.790 & (1.0000) & 592.268 & $(1.0000)$ & 78.5220 & (1.0000) & $11.706( \pm 0.094)$ \\
\hline
\end{tabular}

(a) $\frac{(I)-(I I)}{(I)} \cdot 100=\xi_{i} \cdot 100$

cessively greater forces, and hence they are generally released in that order when the meteorites are heated. The xenon fractions with strange isotopic compositions are released at temperatures $600^{\circ}$ to $1,000^{\circ} \mathrm{C}$, when the ratio of the amounts of (b) to (a) is rapidly decreasing in the meteorites. The heavier isotopes of xenon are systematically enriched in (b) relative to (c), and hence the xenon released at temperatures $600^{\circ}$ to $1,000^{\circ} \mathrm{C}$ often appears to be severely mass-fractionated in such a manner that the abundances of the heavier isotopes are markedly enhanced. The abundances of the three lightest isotopes are also enhanced in the xenon fractions released at $600^{\circ}$ to $1,000^{\circ} \mathrm{C}$, because the release of excess light isotopes from the meteorites occurs in the same temperature range. Further experimental studies along these lines are in progress in our laboratories and the results from these studies will be reported in the near future.

Acknowledgment-This investigation was supported by the National Science Foundation under Grant NSF EAR 76-00285. 
Table 12. Isotopic composition of the xenon in Allende 3CS4. The values of $\Delta_{i}, \nu_{i}$ and $\delta_{i}$ for Allende 3CS1 used in these calculations are shown in Table 10.

\begin{tabular}{|c|c|c|c|c|c|c|c|c|c|}
\hline $\begin{array}{l}\text { Mass No. } \\
i\end{array}$ & $\Delta_{\mathrm{i}}^{\prime}$ & $\nu_{\mathrm{i}}^{\prime}$ & $\delta_{\mathrm{i}}^{\prime}$ & $V^{\mathbf{i}}$ & $\nu_{\mathrm{i}}^{\prime \prime}$ & $V^{i} \cdot \nu_{\mathrm{i}}^{\prime \prime}$ & $\delta_{\mathrm{i}}-\delta_{\mathrm{i}}^{\prime}$ & \multicolumn{2}{|c|}{$\begin{array}{c}\text { Isotopic composition of the } \\
\text { xenon in Allende 3CS4 } \\
R^{\mathrm{i}} \quad R^{\mathrm{i}} \\
\text { (Calculated) (Experimental) }\end{array}$} \\
\hline 124 & $\begin{array}{r}0.00010 \\
\pm 0.00005\end{array}$ & 0.99344 & 0.000749 & 0.01442 & -0.14582 & -0.00210 & $\begin{array}{c}0.011 \\
\pm 0.0037\end{array}$ & $\begin{array}{r}0.0089 \\
\pm 0.0037\end{array}$ & $\begin{array}{r}0.01247 \\
\pm 0.00027\end{array}$ \\
\hline 126 & $\begin{array}{l}0.00027 \\
\pm 0.0003\end{array}$ & 0.99453 & 0.002025 & 0.01271 & 0.04519 & 0.00057 & $\begin{array}{r}0.0067 \\
\pm 0.0022\end{array}$ & $\begin{array}{r}0.0073 \\
\pm 0.0022\end{array}$ & $\begin{array}{r}0.00835 \\
\pm 0.00039\end{array}$ \\
\hline 128 & $\begin{array}{r}0.0010 \\
\pm 0.0024\end{array}$ & 0.99562 & 0.00751 & 0.2543 & 0.2362 & 0.06693 & $\begin{array}{r}0.086 \\
\pm 0.019\end{array}$ & $\begin{array}{r}0.153 \\
\pm 0.019\end{array}$ & $\begin{array}{r}0.151 \\
\pm 0.002\end{array}$ \\
\hline 130 & $\begin{array}{c}0.0044 \\
\pm 0.005\end{array}$ & 0.99672 & 0.03308 & 0.5025 & 0.42713 & 0.2146 & $\begin{array}{r}0.052 \\
\pm 0.005\end{array}$ & $\begin{array}{r}0.267 \\
\pm 0.005\end{array}$ & $\begin{array}{r}0.272 \\
\pm 0.002\end{array}$ \\
\hline 131 & $\begin{array}{r}0.016 \\
\pm 0.002\end{array}$ & 0.99726 & 0.1204 & 2.543 & 0.52264 & 1.329 & $\begin{array}{r}0.096 \\
\pm 0.016\end{array}$ & $\begin{array}{r}1.425 \\
\pm 0.016\end{array}$ & $\begin{array}{r}1.434 \\
\pm 0.012\end{array}$ \\
\hline 132 & $\begin{array}{c}0.0128 \\
\pm 0.020\end{array}$ & 0.99781 & 0.0963 & 3.116 & 0.61815 & 1.926 & $\begin{array}{l}-0.202 \\
\pm 0.163\end{array}$ & $\begin{array}{r}1.724 \\
\pm 0.163\end{array}$ & $\begin{array}{r}1.715 \\
\pm 0.014\end{array}$ \\
\hline 134 & - & - & - & 1.188 & 0.8090 & 0.9610 & - & $\begin{array}{r}0.961 \\
\pm 0.050\end{array}$ & $\begin{array}{r}0.960 \\
\pm 0.007\end{array}$ \\
\hline 136 & - & - & - & 1.000 & 1.0000 & 1.0000 & - & 1.0000 & 1.0000 \\
\hline
\end{tabular}

\section{REFERENCES}

ANDERS, E., Higuchi, H., Gros, J., TaKahaShi, H., and MORGAN, J.W. (1975) Extinct superheavy element in the Allende meteorite. Science 190, 12621271.

BLACK, D. C. (1975) Alternative hypothesis for the origin of CCF xenon. Nature 253, 417-419.

Clayton, D. D. (1975) Extinct radioactivities: trapped residuals of presolar grains. Astrophys. J. 199, 765-769.

Clayton, D. D. (1976) Spectrum of carbonaceouschondrite fission xenon. Geochim. Cosmochim. Acta 40, 563-565.

Funk, H., Podosek, F. and Rowe, M. W. (1967) Fissiogenic xenon in the Renazzo and Murray meteorites. Geochim. Cosmochim. Acta 31,1721-1732.

KURODA, P. K. (1960) Nuclear fission in the early history of the earth. Nature 187, 36-38.

Kuroda, P. K. (1971) Temperature of the sun in the early history of the solar system. Nature Phys. Sci. 230, 40-42.

KURODA, P. K. (1976a) Xenon isotope anomalies and extinct superheavy elements in carbonaceous chondrites. Geochem. J. 10, 25-31.

KURODA, P. K. (1976b) Determination of the decay products of extinct radionuclide plutonium-244 in meteorites. Radiochem. Radioanal. Lett., 25 (5-6), $365-376$.

KURODA, P. K. (1976c) Xenon-iodine dating: primordial xenon in meteorites. Geochem. J., in press.

Kuroda, P. K. and Manuel, O. K. (1970) Mass fractionation and isotope anomalies in neon and xenon. Nature 227, 1113-1116.

Kuroda, P. K., BECK, J. N., EfURD, D. W. and MILLER, D. K. (1974) Xenon isotope anomalies in the carbonaceous chondrite Murray. J. Geophys. Res. 79, 3981-3992.

Kuroda, P. K., Sherrill, R. D., EFurd, D. W. and BECK, J. N. (1975) Xenon isotope anomalies in the carbonaceous chondrite Murchison. ibid. 80, 15581570.

Lewis, R. S., SRINIVASAN, B. and ANDERS, E. (1975) Host phase of a strange xenon component in Allende. Science 190, 1251-1262.

Manuel, O. K., Wright, R. J., Miller, D. K. and KURODA, P. K. (1972a) Isotopic compositions of rare gases in the carbonaceous chondrites Mokoia and Allende. Geochim. Cosmochim. Acta 36, 961-983.

ManUel, O. K., Hennecke, E. W. and Sabu, D. D. (1972b) Xenon in carbonaceous chondrites. Nature Phys. Sci. 240, 99-101.

PePin, R. O., Nyquist, L. E., PhinNey, D. and BLACK, D. C. (1970) Rare gases in Apollo 11 lunar material. Proc. First Lunar Sci. Conf. Geochim. Cosmochim. Acta. Suppl. 1, Vol. 2, 1435-1454.

Podosek, F. A., Huneke, J. C., BurnetT, D. S. and WASSERBURG, G. J. (1971) Isotopic composition of xenon and krypton in the lunar soil and in the solar wind. Earth Planet. Sci. Lett. 10, 199-216.

PhinNeY, D. L. (1971) Heavy rare gases in selected meteorites and terrestrial materials. Ph. D. thesis, Univ. of Minn., Minneapolis, 1-117.

REYNOLDS, J. H. (1960a) Determination of the age 
of the elements. Phys. Rev. Lett. 4, 8-10.

REYNOLDS, J. H. (1960b) Isotopic composition of primordial xenon. ibid. 4, 351-354.

REYNOLDS, J. H. (1963) Xenology. J. Geophys. Res. 68, 2939-2956.

REYNOLDS, J. H. and TURNER, G. (1964) Rare gases in the chondrite Renazzo. ibid. 69, 3263-3281.
Rowe, M. N. (1968) On the origin of excess heavy xenon in primitive chondrites. Geochim. Cosmochim. Acta 32, 1317-1326.

SABU, D. D., Hennecke, E. W. and Manuel, O. K. (1974) Trapped xenon in meteorites. Nature 251, 21-24. 